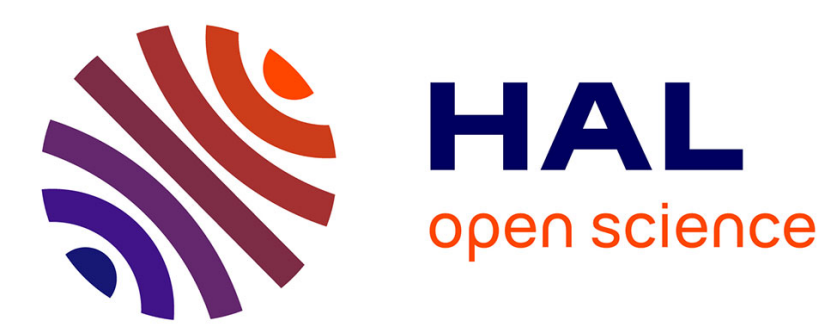

\title{
Parental divorces and children's educational outcomes in Senegal
}

Juliette Crespin-Boucaud, Rozenn Hotte

\section{To cite this version:}

Juliette Crespin-Boucaud, Rozenn Hotte. Parental divorces and children's educational outcomes in Senegal. 2020. halshs-02652221v1

\section{HAL Id: halshs-02652221}

\section{https://shs.hal.science/halshs-02652221v1}

Preprint submitted on 29 May 2020 (v1), last revised 12 Jan 2021 (v2)

HAL is a multi-disciplinary open access archive for the deposit and dissemination of scientific research documents, whether they are published or not. The documents may come from teaching and research institutions in France or abroad, or from public or private research centers.
L'archive ouverte pluridisciplinaire HAL, est destinée au dépôt et à la diffusion de documents scientifiques de niveau recherche, publiés ou non, émanant des établissements d'enseignement et de recherche français ou étrangers, des laboratoires publics ou privés. 


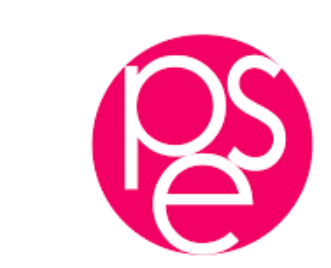

PARISSCHOOLOFECONOMICS
ECOLED'ECONOMIEDEPARIS

WORKING PAPER N²020 - 32

Parental divorces and children's educational outcomes in Senegal

Juliette Crespin-Boucaud

Rozenn Hotte

JEL Codes: J12, I25, 055

Keywords: Divorce, Education, Senegal

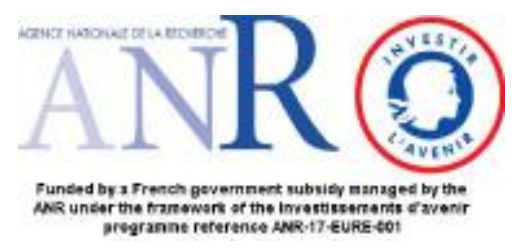




\title{
Parental divorces and children's educational outcomes in Senegal
}

\author{
Juliette Crespin-Boucaud* and Rozenn Hotte ${ }^{\dagger *}$
}

May 28, 2020

\begin{abstract}
This paper studies the impact of divorce on investments in children's human capital at the primary school level in Senegal. We use a siblings fixed-effects estimation that exploits the variations in the age of the siblings at the time of divorce while controlling for family-invariant omitted variables. We compare children who were old enough to have been enrolled in primary school to their younger siblings, for whom enrollment decisions had not yet been taken at the time of the divorce. We find that younger siblings are more likely than their older siblings to have attended primary school, but there are no differences between siblings when considering primary school completion. Overall, divorce does not seem to have negative consequences on whether children have ever been enrolled in primary school.
\end{abstract}

JEL Classification: J12, I25, 055

Keywords: Divorce, Education, Senegal.

"Paris School of Economics (PSE); Address: Paris School of Economics, office R6-01, 48 boulevard Jourdan, 75014 Paris ; E-mail: juliette.crespinboucaud@psemail.eu

†THEMA, Université de Cergy-Pontoise; Address: office 142 A, 33 boulevard du Port, 95000 Cergy ; E-mail: rozenn.hotte@cyu.fr

*We thank Denis Cogneau and Sylvie Lambert for their general advice and their detailed comments that greatly improved the quality of this paper. We are grateful to Sarah Deschênes, Hélène Le Forner, Alexis Le Nestour, Martin Ravallion, Dominique Van de Walle, Oliver Vanden Eynde and Paola Villar for insightful discussions and feedback on previous versions of this paper. We also thank participants of the PSI-PSE and CFDS seminars at the Paris School of Economics (PSE), of the internal seminar of the Department of Economics of the University of Sussex, of the CSAE Conference in Oxford, of the Nordic Conference on Development Economics in Copenhagen, of the Journées Augustin Cournot in Strasbourg, of the LAGV Conference in Aix-en-Provence and of the DIAL Conference in Paris for their helpful comments. Remaining errors are ours. 


\section{Introduction}

Changes in family structure, due to parental death or divorce, are likely to affect children. The potential impacts of divorce and parental death on children in developing countries may be different from what is found in developed countries, as formal safety nets are scarce and poverty levels higher in developing countries. Yet, while the consequences of orphanhood have been studied, little is known about the consequences of divorces for children in sub-Saharan Africa, despite the fact that around 25\% of first unions end by a divorce (Clark and Brauner-Otto, 2015). One key outcome that could be affected by divorce is children's education, as a divorce is likely to imply economic losses, changes in caregivers, and psychological distress (Amato, 2000). As universal primary education has not yet been achieved in all of sub-Saharan Africa, it is important to understanding whether a divorce affects children's access to school.

This paper addresses whether a divorce affects the (basic) educational decisions parents make for their children. We focus on the case of Senegal, complementing a scarce body of work on divorce and schooling outcomes in sub-Saharan Africa (Gnoumou Thiombiano et al., 2013; Chae, 2016). Characteristics of divorced couples are likely to differ between countries, due to difference in norms about marriage, most notably the acceptability of divorce and of polygamy - polygamy being a possible substitute to divorce for some men. The impact of a divorce on children is likely to vary depending on their parents' characteristics, on the level of support from their family network, and on social norms. In Senegal, about $20 \%$ of first unions end by a divorce (Clark and Brauner-Otto, 2015). Couples with children who divorce are more likely to come from better-off backgrounds, but there are divorces among couples from all backgrounds (Lambert et al. (2019), on the same dataset as us).

We study whether age at divorce is correlated to primary schooling decisions, using a sibling fixed-effect specification. The sibling fixed-effect strategy allows to control for all factors that are common to all children in a family, such as father and mother preferences regarding education or the level of education of their parents (Björklund and Sundström, 2006; Le Forner, 2020). This strategy only uses (within-family) differences in age at divorce, thus allowing us to avoid issues related to the selection of families into divorce. We compare children for whom schooling decisions had not been made at divorce date to their older siblings for whom schooling decisions had likely been made at divorce date. We study two related primary schooling outcomes. The first outcome is whether a child has ever attended school (primary school attendance). It captures the lowest level of schooling that a child can have. As the Senegalese education law mandates that children start primary school at age 6 , we consider that a divorce can only affect parents' decision to send their child to primary school if the child was 5 or younger at divorce date. In order to study retention in 
the educational system, we study as a second outcome whether a child has completed 5th grade. This outcomes captures higher levels of investment in schooling.

We use the 2011 wave of the survey Pauvreté et Structure Familiale (PSF, De Vreyer et al. (2008)). This survey combines two elements that are key to implement the sibling fixed effects identification strategy and whose combination is rarely found in household surveys. The PSF survey collected detailed information on marital histories, including the date when and the reason why - divorce or death - each marital union ended. It also collected information on all children younger than 25 born to individuals in a surveyed household, including children who do not live in the household. As custody of children is an outcome of divorce, information on children who are not household members ensures that the sample is not selected as a result of divorce.

Overall, our findings suggest that divorce does not affect negatively educational outcomes of children who were young when their parents divorced. First, having divorced parents is not associated to worse primary schooling outcomes. Divorced mothers are more educated than mothers who never divorced (Lambert et al., 2019), but once mother's education is controlled for children whose parents divorced are not more likely to have attended school than other children. Second, children who were 5 or younger when their parents divorced are more likely to have attended primary school than other children. Using sibling fixed-effects, we find that these children are also more likely to have attended primary school than their siblings who were older than 6 at divorce date. This result is robust to varying the age cutoff for the age at divorce. The magnitude of the coefficient is similar when using a sibling-pair difference model instead of a siblings fixed effects model. Results are not driven by older siblings being less likely to attend school than children of non divorced parents. Third, higher levels of primary school attendance do not result in a higher likelihood to have completed 5 th grade for children who were 5 or younger when their parents divorced. Similarly, children aged 6-9 at divorce date are as likely as their older siblings to have completed 5th grade, indicating that conflict at home while children are in primary school might not be what drives our results. The positive result on school attendance must be nuanced: a higher investment in the lowest level of primary schooling does not seem to lead to a sustained enough investment for children to be able to complete 5th grade. Fourth, custody and fostering decisions does not seem to drive the positive effect on primary school attendance. A potential channel to explain these results is that women might see their decision-making power increase after a divorce, and might then be able to invest more in their children by sending them to school, but that this investment is not sufficient to allow them to complete higher primary education.

This paper contributes to our understanding of how changes in family composition affect children's outcomes, thus relating to the literature on the impact of divorce and parental absence. 
This paper presents results on educational outcomes of Senegalese children whose parents divorced. This paper makes two contributions to the literature. First, we provide new evidence that divorces do not necessarily negatively affect children's basic educational outcomes, using a sibling fixed effect methodology that allows to control for selection into divorce. ${ }^{1}$ While finding no negative impact of divorce on schooling outcomes may be surprising, it is in line with recent evidence on health outcomes of children whose parents divorce. Smith-Greenaway (2020) concludes that in sub-Saharan Africa following divorce, children's health benefits from their biological parents' education to the same degree as children with married parents, highlighting that selection into divorce and remarriage might be what drives the differences observed between children (Clark and Hamplová (2013) and Gnoumou Thiombiano et al. (2013) conclude that children of divorced mothers have worse health outcomes than children whose parents are still married).

Second, this paper expands the literature on the link between divorce and children's education in developing countries by providing results for a country in West Africa. Chae (2016) is the only other paper in which selection issues are discussed. Using child fixed effects, she finds that parental divorce in rural Malawi is associated with a lower grade attainment and a lower likelihood for children to be attending school at the time of the survey. Our findings are at odds with hers, which might indicates that differences in selection into divorce across countries are driving the results. Chae (2016) uses data on children in rural Malawi whereas we use data on children in rural and urban Senegal: divorces are much more common in rural Malawi (40-65\% of first unions end by a divorce) than they are in Senegal. Relatedly, divorced mothers in her sample are much less educated than divorced mothers in our sample, and the large difference in divorce rates between the two countries suggest that the selection into divorce is different, even for a given education level. Divorced mothers in Senegal might not be comparable to divorced mothers in Malawi: in the Senegalese case, children of divorced parents do not seem to have worse schooling outcomes due to their parents' divorce.

The rest of the paper is organized as follows. We introduce the dataset and survey used for our analysis in section 2. Section 3 introduces elements of context about divorce and education au Senegal. Section 4 details the identification strategy. Section 5 presents the results. Section 6 provides robustness checks. Section 7 concludes.

\footnotetext{
${ }^{1}$ When considering the broader category of paternal absence, the consensus seems to be that death of the father has either negative or no consequences for his children, depending on the outcome considered (van de Walle, 2013; Beegle et al., 2006) and that the death of the mother had negative consequences for her children (Case and Ardington, 2006; Beegle et al., 2010). A divorce does not necessarily imply paternal absence and the impacts of both shocks are likely to differ due to differences in the type of shock as well as differences in the characteristics of families affected by these shocks.
} 


\section{Data: Pauvreté et structure familiale}

We use the second wave of the survey Enquête Pauvreté et Structure Familiale ${ }^{2}$ (PSF) that was conducted in Senegal in 2011. ${ }^{3}$ The survey is described in detail in De Vreyer et al. (2008).

The PSF database allows us to study divorces in Senegal due to two features of the survey. First, PSF records detailed information on past marital life, allowing us to identify the last marital breakdown (due to divorce or widowhood) that women experienced. Respondents are asked when their current and last unions began and ended, allowing us to identify the children born to each union. Respondents are also asked how many times they experienced a marital dissolution, and what was the reason why their last union ended (if any). Second, PSF lists all the children of household members, provided that they are younger than 25 years old. Each individual in the household is asked to indicate which children living in the household are her own, and to list her children living elsewhere. Thus, there is no selection of children based on whom they live with, ensuring that our results are not biased by decisions regarding custody and place of residence of children after a divorce.

We focus on divorced mothers and their children, and do not study fathers who have divorced. There are two reasons for that choice. First, when a man had several wives at the time when he divorced one of them, we cannot reliably identify which children were affected by the divorce, as we do not know which of this then-wives he divorced from. Second, in a context where polygamy rates are high and where polygamous men have many children, ${ }^{4}$ women are more likely to accurately report the age of their children. Knowing when children were born allows us to compute their age at the date when their parents divorced. The data we use is partly retrospective - year of marriage and divorce - and concerns in some case children who are not household members. Misreporting should not be a major issue, as it is likely that mothers remember birth, marriage, and divorce years, and know about whether their children went to school, even if they are not living in the same household as them.

There are two main limitations to using PSF. First, households where divorced women live at the time of the survey are not the households in which these women and their children lived before the divorce. ${ }^{5}$ Information on the previous household is more limited than information on

\footnotetext{
${ }^{2}$ Momar Sylla and Matar Gueye of the Agence Nationale de la Statistique et de la Démographie of Senegal (ANSD), and Philippe De Vreyer (University of Paris-Dauphine and IRD-DIAL), Sylvie Lambert (Paris School of Economics-INRA) and Abla Safir (World Bank) designed the survey. The data collection was conducted by the ANSD.

${ }^{3}$ The first PSF wave is a representative sample of the Senegalese population, the second wave included respondents of the first wave and the household members living with them. The number of respondents is almost two times higher in the second wave (28 000 individuals versus 14 450) than in the first one. The sample of interest is not large enough in PSF1, hence our decision to use PSF2.

${ }^{4} 43 \%$ of married men older than 45 years old have more than one wife. Polygamous men who live with all their wives have on average 7.5 children.

${ }^{5}$ We can retrieve information on the household that existed before the divorce only when the divorce took place
} 
the current household: we do not have retrospective information on the exact place of residence when the child was in school, we only know whether she was in the household or had already left it. Second, information collected on children who do not live in the household where their mother lives is more limited than what is collected on children living with their mother. Two types of education-related questions are asked about children who are not living in the household: whether the child has ever attended primary or secondary school and at which level, and whether the child is currently attending school. Information on the age at which a child started school was collected only for children living in the household.

\section{Background: Divorce and Education in Senegal}

We introduce in this section elements of context that are needed to understand the two phenomena studied in this paper. First, we provide descriptive statistics on divorce in Senegal and link them to qualitative evidence on the matter. Second, we describe the Senegalese educational system and explain which dimensions of primary schooling the outcome variables capture.

\subsection{Insights on divorces in Senegal}

We first present background information on how divorces take place in Senegal. We then describe the characteristics of divorced mothers and of their children.

\subsubsection{Two different worlds: Legal and customary divorces}

We count as a divorce any union that ended for reasons other than the husband's death. Respondents report when each of their marital unions ended: the date of divorce is based on selfdeclaration and likely reflects the time when the separation became effective, rather than the end of an eventual legal process. ${ }^{6}$ Our data does not allow us to distinguish between legal divorces and customary ones. Actually, since 1973, according to the Code Sénégalais de la Famille, a legal marital dissolution must be pronounced, even if the marriage is not legally registered. However, qualitative work conducted by one of the authors suggests that most women do not formally divorce.

A report by Lagoutte et al. (2014) provides detailed information and analyzes of marital dissolutions practices in Senegal. The provisions on divorce in 1973 Senegalese family law aimed at protecting women and ensuring gender equality: both parties can file for divorce. It supersedes

between the two waves. There are only 65 women who divorced between the two waves. Among these 65 women, only 43 had at least one child with their then husband, and among them, only a few had attained schooling age in 2011.

${ }^{6}$ There is no heaping on divorce dates with respect to the survey date. 
customary divorce rules. Under customary law, a wife might ask her husband for a divorce, but he needs to agree to it for the divorce to be effective. Conversely, a husband can divorce his wife, even if she do not agree to the divorce. ${ }^{7}$

Women are more likely to file for divorce than men. One of the reason could be the existence of polygamy, allowing men to remarry in case of an unhappy marriage. Women make around $75 \%$ of claims in court. Most of the divorce rulings are granted on the grounds of incompatibilité d'humeur (a rather vague term, literally "mood incompatibilities") or of "défaut d'entretien par le mari" ( husband failed to support his wife economically). ${ }^{8}$ The existence of these two grounds for divorce are anterior to the 1973 Senegalese family law and exist in both the Islamic law and the customary one. When children were born to the divorcing couple, the judge decides on the children's residence and declares one parent to be the main caregiver. Mothers are usually granted custody of their daughters and of their young sons. Child support ${ }^{9}$ can be ordered by the judge. In case of a customary divorce, fathers can claim custody of their children as soon as they are not infants. Lambert et al. (2019), quoting interviews with women, stress that women are often worried that their children could be taken away from them, should they separate from their husbands. When the children stay with their mother, their father might contribute to their living expenses, if he is able and willing to do.

The consequences of a divorce are hence likely to differ vastly across women. On average, according to Lambert et al. (2019), divorcees are not worse-off than other women. Dial (2008) shows that divorce is for some women a means to financial and personal independence. However, women might end up in dire situations, as shown by the fact that almost all sex-workers in Dakar are divorcees (Ito et al., 2018). It could be the case if they did not choose to divorce. We cannot disentangle the type of separation with the data in hand, but we can nevertheless investigate the characteristics of women according to their divorce status.

\subsubsection{Who gets divorced?}

Characteristics of divorced mothers Among mothers of children younger than 25 years old, $11 \%$ have ever divorced. ${ }^{10}$ This share is close to the share of ever divorced women among all women. Panel A of Table 1 contrasts the characteristics of divorced mothers to the characteristics

\footnotetext{
${ }^{7}$ There are reports that repudiation - unilateral divorce right, only granted to the husband -, while outlawed, is still practiced in Senegal. However, no woman ever mentioned having been repudiated during qualitative interviews, which might be due to social stigma associated to the practice.

${ }^{8}$ Lagoutte et al. (2014) reports that few divorces are filed for jointly. The two grounds for divorce most commonly filed for are also likely to hide other reasons for divorce, such as infidelity.

${ }^{9}$ Lagoutte et al. (2014) reports that alimony can be provided if the husband filed for divorce under the motive he does not get along with his wife, or in case of a divorce for a serious illness.

${ }^{10}$ It is important to note that $20 \%$ of women who divorce are childless: those women are not included in our analysis.
} 
of mothers who have never divorced. ${ }^{11}$ Divorced mothers, on average, seem to be better-off that their counterparts: they are more educated, more likely to live in an urban area, and are more likely to come from a rather well-off background, as indicated by the fact that fathers of divorced mothers are more likely to be self-employed and state-employed. This difference is not surprising: women who divorce need to access resources to compensate for the (potential) loss of resources associated with divorce, especially if their ex-husbands provided for them during their marriage. Educated women are likely to have better outside options than uneducated women: they have access to more valuable jobs and to better matches on the (re)marriage market. ${ }^{12}$ Their family network may be able to provide more financial assistance. Additionally, the profession of the father is a proxy for social class and may capture how empowered women are. A similar pattern is found when considering households' per capita consumption levels: divorced mothers are part of households that are on average wealthier. Moreover, conditional on age and education, the ethnic and religions composition is balanced across the two groups. This indicates that social norms and practices related to divorce do not vary much across these groups.

The three most common types of living arrangements for a woman when she divorces are to remarry, to live on her own (if she can afford it), or to move back with her parents. $41 \%$ of divorced women have remarried at the time of the survey. Remarriage tend to happen quickly after a divorce, mostly because social norms dictate that child-bearing age women should be married (Lambert et al., 2019). Multi-generational households are common in Senegal: 11\% of mothers who are not divorced live with at least one of their parents. This share is $42 \%$ among divorced mothers: women who cannot afford to live on their own may need or want to move back to their parents' house in order to benefit for their financial support. ${ }^{13}$

Divorced women are positively selected: either most women in our sample have chosen to divorce their ex-husbands or men do not abandon women who are vulnerable. Either way, getting a divorce is indeed a choice made by at least one half of a couple people make. Parents are likely to be concerned by on the one hand, how breaking up would affect their children and on the other hand, how staying together (for instance, in case of domestic violence or conflict) would affect their children. More specifically, they might have priors regarding the impact of divorce depending on the age of their children and they could time their divorce depending on the characteristics of their children. For instance, parents could decide to divorce while their children are young, in order not expose them to conflict. On the contrary, they might decide to "stay together for the

\footnotetext{
${ }^{11}$ Throughout the paper "divorced mothers" refers to divorced mothers who have, at survey, at least one child younger than 25 who was born from the union that ended in a divorce. Similarly, "mothers" refers to women who have at least one child younger than 25 years old at survey date.

${ }^{12} 76 \%$ of the sample of divorced mothers had already worked before the divorce (and this proportion does not vary according to the educational status).

${ }^{13}$ Parents might also provide logistical help such as taking care of the children as well as emotional support.
} 
children" and wait till their children are older before divorcing. ${ }^{14}$

Timing of divorce: Family composition at divorce date We look at observable characteristics at divorce date to determine whether parents seem to be strategically timing their divorce with respect to observable family characteristics, the number, gender and age of children. First, divorced mothers have on average the same number of still-alive children than their counterparts (bottom lines of Panel A, Table 1)). Second, children whose parents have divorced are similar to children whose parents did not (Panel B, Table 1). The share of girls is the same in both groups. Children of divorced mothers are about one year older than their counterparts which is consistent with the fact that divorced mothers are on average 2 years older than their counterparts. Third, 73\% most divorces occur when the last child is a toddler: the distribution of the age of the youngest child at divorce date and of the number of children by age at divorce are shaped as decreasing exponential functions (Figure 1). Since the average gap between children born to divorced mothers is 3 years, it seems likely that the age distribution at divorce is skewed to the right by the fact that women who do not divorce have another child. Taken together, these findings mean that either it is unlikely that parents time their divorce or that they do time it, but according to vastly different priors. ${ }^{15}$

Figure 1: Family composition at divorce date
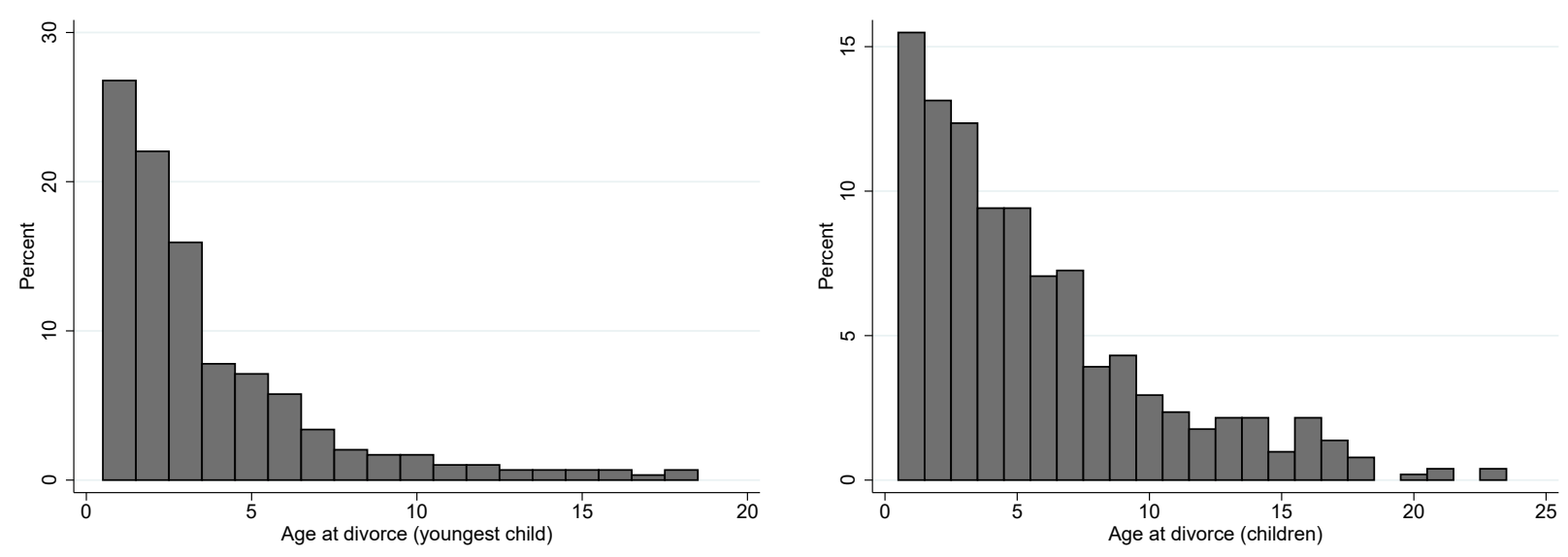

Note: Left panel: Age of youngest child at divorce date, for divorced women with at least a child (born to the union that ended in a divorce) younger than 25 of survey date. Right panel: The distribution of ages at divorce for children whose parents are divorced.

\footnotetext{
${ }^{14}$ From qualitative interviews conducted in Senegal, it seems that some people indeed consider divorces as resulting from a reverse "sympathy shock", that older generations used to endure due to mougne (Wolof term that describes an attitude of resignation that allows to endure difficulties).

${ }^{15}$ Qualitative interviews conducted in Senegal indicate that individual's priors regarding the impact of divorce differ greatly - and seem often correlated to their own experiences.
} 
Table 1: Characteristics of divorced women and of their children

\begin{tabular}{|c|c|c|c|}
\hline & $(1)$ & $(2)$ & (3) \\
\hline Descriptive statistics & Mean & Mean & Diff. \\
\hline Panel A: Women & Has divorced & Never divorced & \\
\hline \multicolumn{4}{|l|}{ Pre-divorce characteristics } \\
\hline Age & 35.83 & 36.20 & 0.38 \\
\hline \multicolumn{4}{|l|}{ Highest education level } \\
\hline No formal education & 0.52 & 0.63 & $0.11 * * *$ \\
\hline Primary & 0.31 & 0.19 & $-0.11 * * *$ \\
\hline Secondary or higher & 0.15 & 0.09 & $-0.07 * * *$ \\
\hline \multicolumn{4}{|l|}{ Ethnicity \& religion } \\
\hline Mourid brotherhood & 0.37 & 0.32 & $-0.05^{*}$ \\
\hline Wolof & 0.47 & 0.43 & $-0.04+$ \\
\hline Serere & 0.12 & 0.12 & -0.00 \\
\hline Poular & 0.26 & 0.22 & $-0.04+$ \\
\hline \multicolumn{4}{|l|}{ Father's occupation } \\
\hline Inactivity of the father of the wife & 0.14 & 0.14 & 0.00 \\
\hline Farmer & 0.27 & 0.41 & $0.14 * * *$ \\
\hline Independant or informal employee & 0.26 & 0.20 & $-0.06 * *$ \\
\hline State-employed or employer & 0.24 & 0.14 & $-0.10 * * *$ \\
\hline Occupation unknown & 0.09 & 0.11 & 0.02 \\
\hline \multicolumn{4}{|l|}{ Characteristics at survey date } \\
\hline Lives in rural area & 0.37 & 0.57 & $0.21^{* * *}$ \\
\hline \multicolumn{4}{|l|}{ Household Consumption pcap } \\
\hline Food expenditures (hh) & 190314.62 & 162679.91 & -27634.70 \\
\hline Other expenditures (hh) & 263200.18 & 159558.63 & $-103641.54 * *$ \\
\hline \multicolumn{4}{|l|}{ Family composition } \\
\hline Mother lives with one of her parent & 0.42 & 0.11 & $-0.32 * * *$ \\
\hline Number of children alive & 3.23 & 3.43 & 0.21 \\
\hline Number of children $(\leq 25$ y.o $)$ & 2.78 & 2.98 & $0.21^{*}$ \\
\hline Number of children - last union ${ }^{\mathrm{a}}$ & 1.78 & 2.87 & $1.10 * * *$ \\
\hline Number of women ${ }^{\mathrm{b}}$ & 287 & 4,095 & 4,382 \\
\hline
\end{tabular}

\section{Panel B: Children}

Age

Birth order

Child is a girl

Child lives with mother

Has been fostered

Has been fostered

\section{Divorced mothers Never divorced}

11.94

10.85

$-1.09 * * *$

2.31

3.34

$1.03 * * *$

0.48

0.49

0.02

0.64

0.85

$0.21 * * *$

0.11

0.06

$-0.04 * * *$

510

12,426

12,936

Note: Column (1) reports the mean of each variable listed for for mothers who have divorced (or their children). Column (2) reports the Note: Column (1) reports the mean of each variable listed for for mothers who have divorced (or their children). Column (2) reports the
mean of each variable listed for mothers who have not divorced (or their children). Column (3) reports the difference between these two mean of each variable listed for mothers who have not divorced (or their children). Column (3) reports the difference between these two
groups and the significance level from a t-test.

Here, never divorced mothers means that they did not divorce from the father of the children present in the our database. The group contains widows.

Sample: Panel A Mothers of at least a child younger than 25 at survey date. Panel B All children

a Number of children younger than 25 born to either current union (if not divorced) or to that last union. Half-siblings of children whose parents divorced are excluded from the sample.

$\mathrm{b}$ The number of observations computed in the last row corresponds to the maximum number of observations in each group. For some characteristics, due to missing values, the number of observations is lower.

Significance levels are denoted as follows: $+\mathrm{p}<0.15,{ }^{*} \mathrm{p}<0.10,{ }^{* *} \mathrm{p}<0.05,{ }^{* * *} \mathrm{p}<0.01$. 
Figure 2: With whom do children usually live?
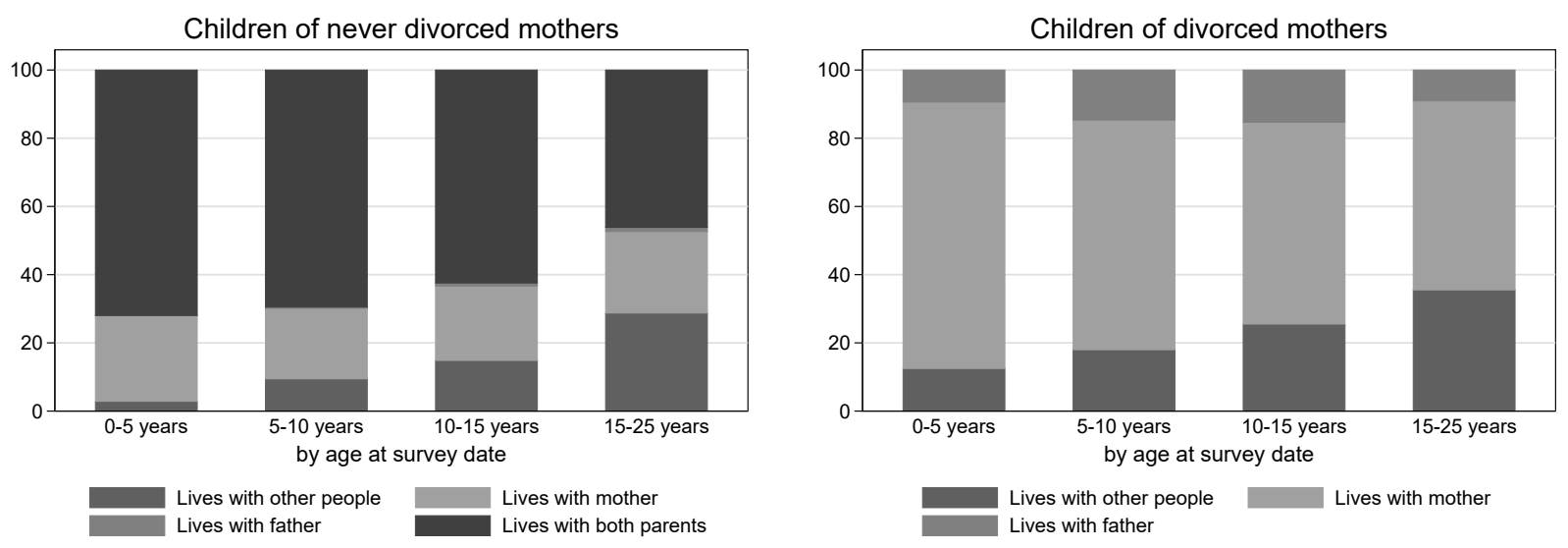

Note: Right panel: Sample: Children whose parents have not divorced. Left panel: Sample: Children whose parents have divorced.

Custody: With whom do children of divorced parents live? $64 \%$ of children of divorced parents live with their mother. Whatever their age, this is the most common case (Figure 2). Still, whether parents are divorced or not, with whom children live is a function of both their age and gender. Teenagers and adults are more likely to live with people who are not their parents, mostly because of marriage or work. ${ }^{16}$ Age-related coresidence patterns vary however more subtly for children whose parents are divorced. Among children whose parents are still together, very few live with their father but not with their mother. This share does not increase with age. Among children of divorced parents, the share of children who live with their father increases when children get older. Second, daughters are less likely to live with their father than sons are (Figure A1, in Appendix). Both findings are consistent with qualitative evidence that suggests that fathers can claim custody of their children once they turn 7 and that they more often live with their sons than with their daughters. Young children who do not live with either of their parents are usually fostered. A fostered child is a child who was sent to live with a host family (often to relatives: grand-parents, an uncle or an aunt) by her parents (Marazyan, 2015). On the same data than ours Beck et al. (2015), find a wide heterogeneity among fostered children in terms of school enrollment, labor or domestic work. Fostering is more common among children of divorced mothers $(11 \%$ against $6 \%)$. This difference remains significant even when controlling for the education of the mother.

\footnotetext{
${ }^{16} 29 \%$ of all young women (15-25) and $4.5 \%$ of all young men are married. This share is lower for children of divorced mothers, $26.6 \%$ and $1.2 \%$ respectively for daughters and sons of divorced mothers but this difference is not statistically significant.
} 


\subsection{Primary education in Senegal}

First, we describe key facts about the education system in Senegal and explain how our outcome variables capture its specificities. Second, we present child-level and family-level determinants of schooling.

\subsubsection{The Senegalese education system}

A dual education system The Senegalese education law mandates that children aged 6 to 16 attend school within the formal school system. ${ }^{17}$ The formal school system consists of 4 educational blocks: pre-school, primary school, secondary schools (middle and high schools), and higher education. Formal schools are referred as either "French schools" or "French-Arabic schools", depending on the languages in which classes are taught. Qur'anic schools (daara in Wolof, Chehami (2016)) are part of the informal education system. While a few Qur'anic schools include both a standard curriculum and a religious one, most focus almost exclusively on religious education (Andre and Demonsant, 2014). The formal and the informal sectors are not necessarily exclusive: children can attend primary school and a part-time Qur'anic school. ${ }^{18}$

Despite the law, not all children attend primary school. Attendance in primary school increases between ages 5 to 7 (Figure 3): most children do start primary school around the age of 6 . Some children start attending school when they are older than $7 .{ }^{19}$ Delayed or absence of entry into primary school may be linked to the fact that the schools supply in rural areas is not high enough (Cissé et al., 2004). Moreover, public schools do not charge school fees, but there are additional monetary cost to attending school, such as transportation fees and books to buy.

Outcome variables: primary school attendance \& primary school completion In this paper, we study two educational outcomes. Our main variable of interest is whether a child has any primary schooling. It hence captures the most basic level of investment in human capital of their children parents can make. If a child has only attended Qur'anic school, but has never attended primary school, she is considered as having no primary education, since the teaching content of Qur'anic school is mainly religious.

The second variable of interest is whether a child has (almost) completed primary school. We consider that a child has completed primary school if she has attended fifth grade (CM1, the second to last grade in primary school). It hence captures a higher level of investment in human

\footnotetext{
${ }^{17}$ As from the law of $n^{\circ} 2004-37$ passed in December 2004, children must be enrolled in school at the age of six. As the survey took place in 2011, children aged 6 at the time of the survey should hence be already attending school.

${ }^{18}$ More that half of children older than 7 who never been enrolled in primary school attended Qur'anic school.

${ }^{19}$ In our sample, $64.8 \%$ of children older than 6 have attended formal school whereas $66.5 \%$ of children older than 10.
} 
capital than whether a child has ever attended primary school. Attending primary school does not necessarily implies completing the primary curriculum: among children who have attended school, $70 \%$ complete their primary education. Several factors explain why the primary completion rate is not higher. First, grade repetition is high in Senegal (Ndaruhutse, 2008). In 2006, 12\% of students had repeated at least a grade ${ }^{20}$. As the opportunity cost of schooling increases with age, grade repetition may increase the likelihood that children drop out of school. Second, the school supply is even more limited for the higher grade of primary education. $36 \%$ of primary schools do not offer the whole primary cycle. ${ }^{21}$

Our data does not allow us to consider other outcomes. More detailed information on schooling outcome, such as at which age a child started school, was collected only for children living in the household. Information on secondary school attendance was collected for all children but as few children attend secondary school, the sample size is too limited for this outcome to be included in the analysis.

Figure 3: Trends in education
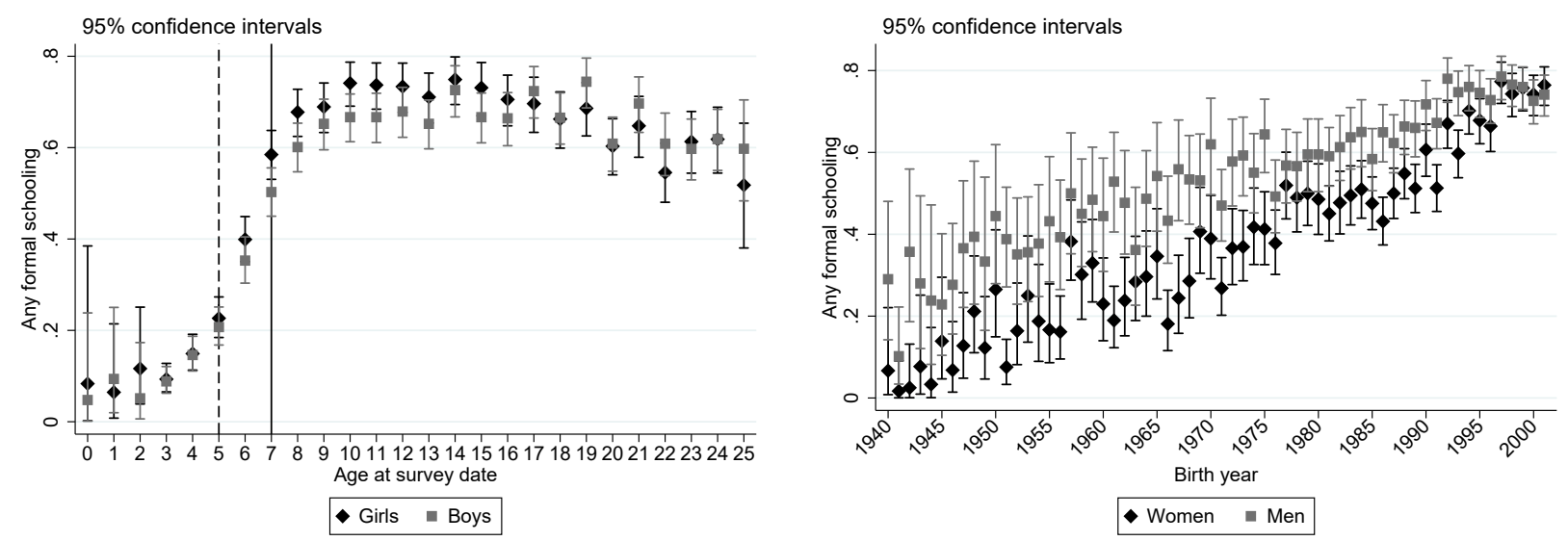

Left panel: Share of children (PSF2) who have attended any kind of formal schooling. Some children attend pre-school, hence they appear as having attended formal school even when they are younger than six, but children who attend formal pre-school usually go on to attend formal primary school.

Right panel: Share of respondents (PSF2) who have any kind of formal schooling, among individuals aged 10 to 70 hence not including younger children.

\subsubsection{Determinants of primary schooling}

Child-level correlates of schooling In order to understand how divorce could impact children's educational outcomes, we first briefly discuss three individual characteristics - birth year, birth order, and rank - that are correlated to the likelihood to have attended school. Regression results are reported in Table A1 in Appendix. In keeping with what we observe in Figure 3, gender and

\footnotetext{
${ }^{20}$ Ministry of Education, Senegal (2006)

${ }^{21}$ Unesco Report for Senegal, 2006.
} 
birth year are correlated to the likelihood to have attended primary school. Girls are more likely to have attended primary school than boys. This difference does not reflect the common idea that girls in sub-Saharan countries are less educated than boys. However, the education rate of girls has converged to the one of boys over the last ten years in Senegal (right panel, Figure 3) ${ }^{22}$. Patterns observed with birth year correspond to what we observe in the figure and are consistent with the increase in schooling supply (Niang, 2014). Higher birth orders are negatively correlated to the likelihood to have attended school.

Family-level characteristics: education of the mother and divorce? In keeping with the vast literature on the links between parental human capital levels and investment in children's human capital (on Senegal, Dumas and Lambert (2011)), the children of educated mothers are more educated than their counterparts. Only $56 \%$ of children whose mother never went to school have ever attended primary school. This share increases to $88 \%$ for children whose mother has attended (not necessarily completed) primary school and 96\% for children whose mother attended secondary school. ${ }^{23}$ The share of children who have completed primary school is respectively $39 \%, 67 \%$, and $80 \%$. As discussed in the above section, divorced mothers are more educated than their counterparts and their children are 6 percentage points more likely to have attended primary schools than children whose parents did not divorce (column 2, Table A2 in Appendix). However, this difference is due to composition effects and disappears once the education of the mother is controlled for. Children whose parents are divorced are not more likely to have completed primary education. However, it is unlikely that primary schooling outcomes of all children whose parents divorce could be affected by it: the consequences of a divorce are likely to be age-specific (for instance, custody) and a divorce might affect children differently depending on their age at the time of divorce.

\section{Methodology}

How are children affected by their parents' divorce? Many confounding factors could explain any difference found between children depending on whether their parents divorced. Short of being able to use exogenous variation in divorce rates, our methodology has two specificities that, taken together, should reduce the bias on the coefficient estimated. The first one is that the main

\footnotetext{
${ }^{22}$ Boys seem to be more likely to having been sent full time to a Qur'aranic school. When we consider whether a child has ever attended school, whether Qur'anic or primary school, we find no difference across gender. We check that this difference on primary school does not arise from measurement error in the PSF survey. Using the Demographic Health Survey for Senegal 2010-2011, we compute primary school attendance for children aged 7 to 15 . $66 \%$ of girls and $63 \%$ of boys have some primary schooling or were attending primary school at survey date.

${ }^{23}$ The median age of children whose mother went to secondary school is 11 years old: the gap to $100 \%$ is not due only to data coming from children aged 7 who join school the following year.
} 
outcome variable we consider, any primary education, is arguably unlikely to be affected by events that took place before the divorce date. The second one is that the specification used includes siblings fixed effects. We detail below our estimation strategy. We then discuss the assumptions we make and the interpretation of our results, before presenting the variation of the methodology used to study our second outcome of interest - completed primary education. Finally, we explain how our estimation sample is defined.

\subsection{Estimation strategy}

\section{Framework}

As discussed in section 3.2, children are supposed to start attending primary school the year they turn 6. If we assume that (1) the decision to send a child to school is already made when the child turns 6 and that (2) the impact of parental divorce starts at the date of the divorce, then the divorce cannot affect whether a child has ever attended primary school if this child was older than 6 when her parents divorced. Under these two assumptions, we consider children who were 5 or younger when their parents divorced as affected by the divorce and children who were 6 or older when their parents divorced as not affected by the divorce in terms of this specific schooling outcome: having attended (some) primary school including being currently attending primary school. ${ }^{24}$ We discuss these assumptions in detail in the next section.

The main outcome variable, AnyPrimarySchool, is an indicator variable that takes the value 1 when a child has attended or is attending primary school, and 0 otherwise. As children are supposed to start primary school when they turn 6 , we consider the outcome variable as defined for children who are 7 or older at survey date. As some children start attending primary school later than age 7 (Figure 3), we also report results when incrementally moving the age cutoff on the outcome variable from 6 to 10 in the section 6.1 .

The main variable of interest AgeAtDivorce $0 / 5$ is an indicator variable that takes the value 1 if a child was 5 or younger when her parents divorced and 0 if either her parents divorced when she was 6 or older or her parents did not divorce. In section 6.1, we report results when varying the age cutoff that defines which children are affected by a divorce and which ones are not.

\section{Model 1: Basic LPM}

\footnotetext{
${ }^{24}$ All children whose parents divorce are affected by the divorce, but older children are not all affected when considering this specific outcome. For instance, if parents cannot keep sending their children to school after their divorce, we would still consider these children as having attended primary school.
} 
We first report results of a linear probability model ${ }^{25}$ without fixed effects, specified as follows:

$$
\text { AnyPrimarySchool }{ }_{i s}=\alpha_{0}+\alpha_{1} \text { AgeAtDivorce } 0 / 5_{i}+\alpha_{2} \text { AgeAtDivorce } 6 / 25_{i}+\beta \text { Controls }_{i}+\epsilon_{i s}
$$

In this equation, $i$ denotes children and $s$ denotes a family (defined as a group of full siblings). AgeAtDivorce $6 / 25_{i}$ is a binary variable that takes the value 1 if the child was 6 or older when her parents divorced, and zero otherwise. Controls $_{i}$ is a vector of individual characteristics that includes the following variables: a binary variable that takes the value 1 if the child is a girl; quadratic controls of year of birth; 4 binary that account for birth order (birth orders higher than 4 are grouped together). In an alternative specification, we add the mother's highest education levels as well as their interaction with the variables already included in Controls $s_{i}$. Indeed, these variables are correlated with the likelihood for a child to have ever attended primary school (section 3.2) and to our variable of interest AgeAtDivorce $0 / 5$ for the education of the mother and the year of birth. ${ }^{26}$ However, our results are not overly sensitive to the inclusion of these control variables: we discuss this point further in section 6.1. Standard errors are clustered at the family (group of siblings) level.

Model 2: LPM with sibling fixed effects We then turn to a sibling fixed effect model. Such models are widely used in the literature on the impact of divorce (Björklund and Sundström, 2006; Le Forner, 2020; Francesconi et al., 2010; Ermisch and Francesconi, 2001; Bratberg et al., 2014).

Including siblings fixed effects is equivalent to controlling for unobserved factors that do not vary across siblings, for instance parental preferences for education if these preferences are the same for all children. The use of siblings fixed effects allows us to "control" for all family-level characteristics. Estimates from this model should hence be less biased than estimates from the basic LPM. The coefficient on AgeAtDivorce $0 / 5_{i}$ in model 2 is an unbiased estimate of the effect of being 5 or younger when one's parents divorced if the unobserved factors that might simultaneously affect the school attendance and the explanatory variable of the regression do not vary across individuals (assumption (3)). We discuss this assumption in the following section. However, it is impossible to completely refute the existence of unobserved factors that would violate

\footnotetext{
${ }^{25}$ We do not estimate logit models as logit models with fixed effects only estimate results for groups in which there is variation in the outcome variable: too many observations are lost and this results in control variables being poorly estimated. Then in order to compare results from the model without fixed effects to results using the sibling fixed effects model, we specify the first one as a linear probability model. The results using a logit are consistent with results estimated used a LPM without sibling fixed effects.

${ }^{26}$ When considering children aged 7 to 25 at the time of the survey, children who were older than 6 at divorce date are 3.8 years older at survey date than children who were 5 or younger. The main factor that explains this age difference is that divorce dates are the same for all the children within a family. Younger children at divorce date are still younger than their older siblings at survey date.
} 
this identification assumption in the case of divorce: we hence interpret our results as correlations, and not as causal estimates, even when fixed effects are added to the model.

$$
\text { AnyPrimarySchool }{ }_{i s}=\alpha_{0}+\alpha_{1} \text { AgeAtDivorce } 0 / 5_{i}+\beta \text { Controls }_{i}+\gamma_{s}+\epsilon_{i s}
$$

In this equation, $i$ denotes children and $s$ denotes a family (defined as a group of full siblings). PrimarySchool $_{i s}$, AgeAtDivorce $0 / 5_{i}$, and Controls $s_{i}$ are defined as in model $1 . \gamma_{s}$ is a sibling fixed effect. Standard errors are clustered at the family (group of siblings) level. As siblings fixed effects are included, the right hand side variables can only be estimated if they vary within families: AgeAtDivorce6 $/ 25_{i}$ cannot be estimated as it is co-linear to AgeAtDivorce $0 / 5_{i}$ once the fixed effects are included. As we compare young children to their older siblings, we need to control for birth cohort and birth order in order not to capture the trends on education (section 3.2) in the coefficient associated to AgeAtDivorce $0 / 5_{i}$.

\subsection{Assumptions and interpretation of the results}

We detail the main assumptions required by our identification strategy and discuss the most obvious confounding factors that come to mind when studying divorces: conflict and the timing of the divorce.

Assumption (3) [SFE assumption]: the timing of divorce is not correlated to any unobserved factor that affects both the outcome and the explanatory variables

Under this assumption, the coefficient associated to being younger than 5 at the time of the divorce would not be biased. Any unobserved factor that varies between children of a family and is correlated to divorce could be a concern. As it is impossible to eliminate completely the concern related to the potential existence of time varying unobservable factors, we interpret the results as correlations and not as causal estimates. We present nevertheless here some arguments addressing the most obvious potential confounding factors. A first concern exists if the likelihood of divorce depends on the educational ability of children. For instance, if parents divorce because one of their children has a disability that prevents her from attending school, and that the stress on the family is too high, leading to a divorce. This scenario is unlikely in the Senegalese context: to the best of our knowledge, having a disabled child was never mentioned as a cause for divorce, in our own qualitative fieldwork or in the research done by others (Dial, 2008). A second concern is if the timing of a divorce is correlated to an economic shock (negative, for instance if one of the parents loses his job, or positive, if one of the parent gets a formal job) that also affects the decision to enroll younger children in primary school. We cannot rule out that this is the case, but discuss the 
implications for our results in section.

Assumption (2): the impact of parental divorce starts at the date of the divorce

This assumption is needed to consider that the primary schooling outcome of some children is not affected by their parents divorce. A first concern is that parents might anticipate the divorce and that the effects of the divorce are not correlated to date of divorce. We try to answer to this concern in section 4.2. A second concern is conflict. For instance, we might think that when the level of conflict is high in a family, the level of parental investment in education is lower, and that after the divorce, the levels of conflict decreases: older children would then be more affected than their younger siblings. Conflict levels are indeed likely to have a differential impact on children depending on their age (both a proxy for cognitive development and for length of exposure to conflict). However, we expect conflict levels to impact children's well-being and, among others, some educational outcomes such as highest level of education completed and test scores, but not necessarily the decision to send a child to school, especially as we consider primary schooling, an outcome that does not come with the same strict age threshold as later-stage schooling outcomes. Moreover, we conduct a placebo test on coefficients at the end of our section 5.1 and show that children aged between 6 and 9 when their parents divorced are not more affected than children who were 10 or older when their parents divorced.

Assumption (1): the decision to send a child to school is already made when this child turns 6 Our estimation strategy only requires a weak version of assumption (1): there is a given age at which schooling decisions have been made for all children. While the age of 6 is our preferred specification, we show in section 6.1 that our results are robust to deviations from this cutoff age for both the sample definition and the age group at divorce variable.

\subsection{Additional outcome: Completed primary schooling}

The variable CompletedPrimary is an indicator variable that takes the value 1 when a child has completed primary school (reaching fifth grade), and 0 otherwise. We consider the outcome variable as defined for children who are 10 or older at survey date. Children who start school at age 6 are supposed to be in fifth grade when they are 10. Children who are not in fifth grade at age 10 are either no attending school anymore or they are attending school in a lower grade (because they repeated a grade or started school a bit later). Assumptions (2) and (3) remain the same, assumption (1) is modified to include the threshold 10. 


\subsection{Sample}

The same sample is used for estimating models with and without fixed effects. We hence restrict our sample to observations that are used to estimate the (more data demanding) sibling fixed effects model. The main sample includes 7,268 children belonging to 2,166 families, of which 263 children, belonging to 101 families, have divorced parents.

There are three criteria that determine whether children are included in our main sample. First, we must know whether children have attended (completed) school or not: we consider that this outcome is defined for children aged 7 (10) or older at survey date (criterion A). Second, we consider a family to include only siblings who have the same biological parents: half-siblings of children whose mother remarried after a divorce or becoming a widow are dropped from the sample (criterion B). ${ }^{27}$ Third, there must be at least two observations (children) by group (family) for which the outcome variable is defined (criterion C), in order to estimate the sibling fixed effects model. In section 6.3 , we relax alternatively criterion B and criterion $C$ and compare our results to results estimated on the main sample (criteria $\mathrm{A}, \mathrm{B}$, and $\mathrm{C}$ ).

\section{Results}

In this section, we first present results from the two specifications describe above. We then discuss which channels could mediate the effects found.

\subsection{Main results}

The results of the basic linear probability model and of the siblings fixed effects model are reported in Table 2. We present first results on primary school (past or present) attendance and second results on primary school completion.

Results: Ever attended primary school Columns (1) and (2) report the results for three basic linear probability models. Column (1) reports the results of a regression of whether the child has attended primary school on indicator variables for age groups at divorce. Being 5 or younger at the time of divorce is associated to a higher likelihood to have attended primary school. When controlling by birth year, birth order, gender and their interactions with the level of education of the mother (column (2)), the magnitude of the coefficient decreases but it remains positive and

\footnotetext{
${ }^{27}$ Birth order is computed using all children born to the same mother, thus including older siblings who are older than 25 and half-siblings. Few children whose parents divorced have older half-siblings and their birth rank is not affected by whether they have younger half-siblings.
} 
significant. On average, children who were 5 or younger when their parents divorced are 11.3 percentage points more likely to have attended primary school than their counterparts whose parents did not divorce: this difference is close to $1 / 5$ of the share of children who have ever attended school (65\% on our estimation sample).

Columns (3) to (5) report the results for three siblings fixed effects models. Being 5 or younger at divorce date is still associated to a higher likelihood of having attended school (column (3)). The inclusion of controls does not change the results much (column (4)): if anything, the coefficient increases when the controls are added. The addition of the sibling fixed effects slightly increases the magnitude of the coefficient of interest (column (2)/column(4)), meaning that it does capture some unobserved characteristics that are common to siblings: the OLS estimates seem to be slightly downward biased compared to results estimated with a SFE model. ${ }^{28}$

Heterogeneity among children and families As girls are on average more likely to attend primary school than boys, we test whether girls' educational outcomes are more affected by a divorce before the age of 5 than boys' outcomes are. The coefficient associated to the interaction term between age at divorce and gender is close to 0 and not significant in both the basic LPM and the SFE models (column (5)): children being younger than 5 at divorce date does not seem differentially affected according to their gender in terms of primary schooling.

So far, we have considered that the schooling outcome of children older than 6 at the time of divorce was not affected by the divorce. However, if we only consider the results of column (5), then we cannot know whether the positive effect on being younger than 5 at divorce date is due to the fact that children younger than 5 at divorce date have better schooling outcomes than what would have been expected in the absence of divorce or to the fact that children older than 6 at divorce date have worse schooling outcomes than what would have been expected in the absence of divorce.

In order to understand which ages at divorce drive the differences in schooling we observe, we modify our regression equations to introduce binary variables for each age at divorce (for ages at

\footnotetext{
${ }^{28}$ Since the introduction of SFE changes the observations on which the coefficient of interest is identified (the coefficient in the LPM model being also estimated on families who all children are younger than 5 at the time of divorce, when it is no the case when adding SFE), we redo the analysis excluding in the basic LPM model the additional identifying observations (Columns (3) and (4) in Table A5). Comparing column (3) to column (4), the magnitude of the coefficient on the age at divorce seems also to increase (from 0.135 to 0.167 ) when including the sibling fixed effect, confirming that the Basic LPM estimates seem to be slightly downward biased.
} 
Table 2: Effect of parental separation on primary attendance and completion

\begin{tabular}{|c|c|c|c|c|c|c|c|}
\hline & (1) & (2) & (3) & (4) & (5) & (6) & (7) \\
\hline Specification & LPM & LPM & SFE & SFE & SFE & SFE & SFE \\
\hline Sample & \multicolumn{5}{|c|}{ Main sample, 7 years old } & \multicolumn{2}{|c|}{ Main sample, 10 years old ${ }^{a}$} \\
\hline Dependent variable & \multicolumn{5}{|c|}{ Ever attended primary school } & \multicolumn{2}{|r|}{ Completed } \\
\hline \multicolumn{8}{|l|}{ Age at divorce } \\
\hline \multirow[t]{2}{*}{$0-5$ у.о. } & $0.151 * * *$ & $0.113 * *$ & $0.139 * *$ & $0.168 * * *$ & $0.141^{* *}$ & 0.164 & 0.0229 \\
\hline & $(0.0466)$ & $(0.0455)$ & $(0.0616)$ & $(0.0619)$ & $(0.0624)$ & $(0.115)$ & $(0.137)$ \\
\hline \multirow[t]{2}{*}{$0-5 \times$ girl } & & & & & 0.0527 & & \\
\hline & & & & & $(0.0912)$ & & \\
\hline \multirow[t]{2}{*}{ 6-9 у.о. } & & & & & & 0.0291 & 0.0156 \\
\hline & & & & & & $(0.0920)$ & $(0.103)$ \\
\hline \multirow[t]{2}{*}{ 6-25 у.о. } & -0.0206 & -0.0696 & & & & & \\
\hline & $(0.0513)$ & $(0.0500)$ & & & & & \\
\hline \multirow[t]{2}{*}{ Girl } & & & & & 0.00946 & & \\
\hline & & & & & $(0.00978)$ & & \\
\hline Controls & No & Yes & No & Yes & Yes & Yes & Yes \\
\hline Controls $\times$ educ & No & Yes & No & Yes & No & No & No \\
\hline Share primary & 0.65 & 0.65 & 0.65 & & 0.65 & 0.66 & 0.47 \\
\hline pvalue - joint significance & & & & & 0.03 & & \\
\hline $\mathrm{R}^{2}$ & 0.0014 & 0.1147 & 0.0011 & 0.0544 & 0.0310 & 0.0262 & 0.0952 \\
\hline $\mathrm{N}$ observations & 7,268 & 7,268 & 7,268 & 7,268 & 7,268 & 5,568 & 5,568 \\
\hline $\mathrm{N}$ families & & & 2,166 & 2,166 & 2,166 & 1,770 & 1,770 \\
\hline N identifying obs. (0-5) & 171 & 171 & 134 & 134 & & 127 & 127 \\
\hline $\mathrm{N}$ identifying families (0-5) & & & 47 & 47 & & 47 & 47 \\
\hline \multicolumn{8}{|c|}{ 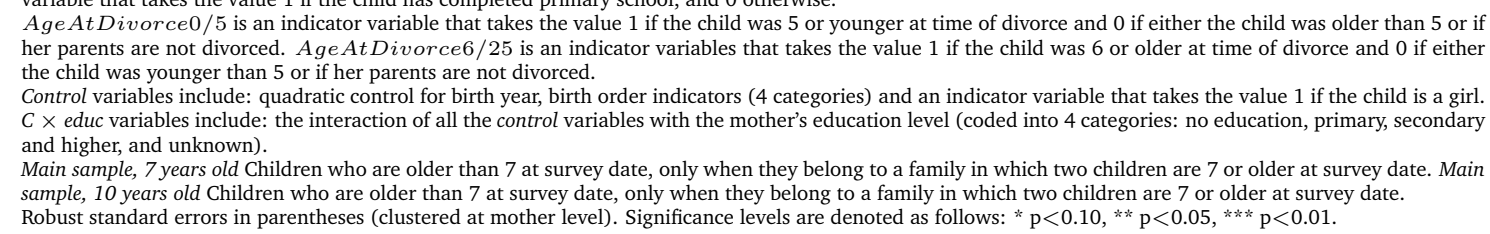 } \\
\hline
\end{tabular}

divorce 0 to 6 ) instead of using only two categories ( 5 and younger / 6 and older) ${ }^{29}$. Figure 4 shows the coefficients associated to these age at divorce variables. In the left panel, the reference group is children who were older than 7 when their parents divorced. Our results do not seem to be driven by a specific age group for ages at divorce between 1 and 5 . In the right panel, the reference group is children who were older than 10 when their parents divorced. Setting a higher age cutoff for inclusion into the sample allows us to estimate the coefficient associated to age at divorce variables for later ages. The coefficients estimated on all the variables for ages at divorce between 6 and 9 are close to 0: the children whose parents divorced when they were between 6 and 9 have the same likelihood to attend primary school that children who were older than 10 when their parents divorced. Similarly, the coefficient associated to being between 6 and 25 at divorce date is not significant in the columns (1) and (2): the attendance outcome for children

\footnotetext{
${ }^{29}$ The effects are hence identified using a larger set of observations/families as we can leverage variation within the age group 0-5.
} 
older than 6 at the time of divorce is not different from the attendance outcome for children whose parents did not divorce. Thus it seems that the coefficient on being younger than 5 at the time of divorce comes from children younger than 5 at divorce date being more educated than what could be expected, rather than from children older than 6 at divorce date being less educated than what could be expected.

On average, the effect on younger children is positive: hence, in order to estimated a positive coefficient using within-family variation, we need that some children who were older than 5 do not go to school. The share of children older than 5 at divorce date who attended primary school is $50 \%$ when we consider children of uneducated mothers, whereas this share is $74 \%$ when mothers themselves attended primary school, and 91\% when mothers attended secondary school. Hence, it seems that the variation observed comes from children of uneducated mothers. We cannot test directly that idea as there are too few observations to estimate interaction terms of age at divorce with education of the mother.

Figure 4: Coefficients on age at divorce
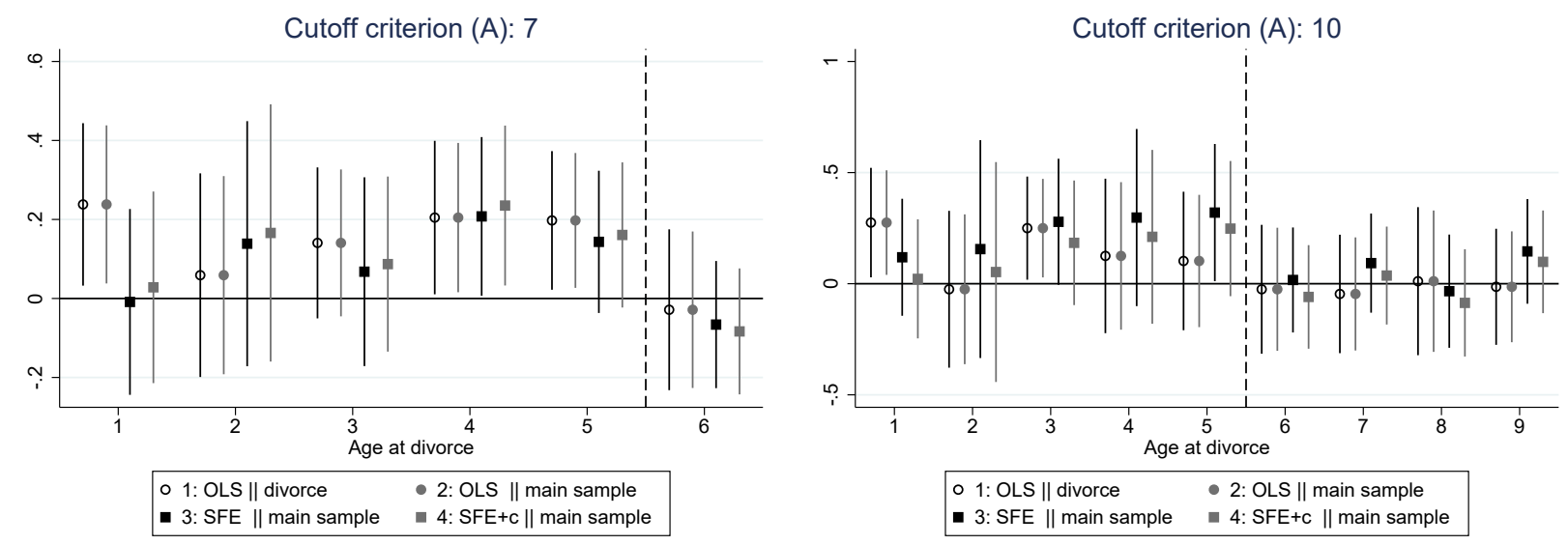

Note: Left panel: At least 2 children older than 7 at survey date. Right panel: At least 2 children older than 10 at survey date. Specifications: (1) LPM only on children of divorced parents; (2) LPM on all children (with additional variable Divorce); (3) SFE on all children $(\approx$ column $(3)$, Table 2$) ;(4)$ SFE with controls on all children $(\approx$ column (4), Table 2)

Results: Completed primary Column (7) reports the results when considering whether a child has completed primary school (5th grade) instead of whether she ever attended school. Being younger than 5 at the time of the survey is not associated to a higher likelihood to complete primary schooling: the magnitude of the coefficients associated to both age group categories is extremely low. Column (6) report the results for primary school attendance on the sample of children older than 10 at survey date. The coefficient on being younger than 5 at divorce date is not significant due to the loss of power, but its magnitude remains the same as when it is estimated on the sample of children older than 7. Children between 6 and 9 are unaffected, which is in line 
with the results of Figure 4. These results show that younger children at divorce date may be more likely to attend primary school (column 6), but this effect does not seem to persist (column 7).

Since we study children who are 10 or older at the time of the survey, some might still be in primary school, but not in fifth grade yet, due to frequency of grade repetition. We do not find a positive impact when looking at children older than 11 or 12 at the time of the survey neither. Children who were between 6 and 9 are not more likely to complete primary school than children whose parents divorced when they were 10 or older. Divorce does not seem to be correlated with educational attainment for children who are already in school at the time of divorce.

\subsection{Channels}

In this section, we discuss what might explain the results on primary school attendance and on primary school completion. We first test whether custody and fostering decisions could be driving the results. We then consider factors related to income, access to non-monetary resources, and bargaining power.

\subsubsection{Custody and fostering decisions after divorce}

Custody and fostering decisions We discuss whether with whom the child lives after the divorce matters for educational outcomes. Parents might have different preferences regarding their child's education, so educational outcome of children might depend on which parent gets custody. When parents foster their child they are likely to foster her to relatives who have the same preferences for education as them, but who might have access to more resources. The estimates regarding custody and fostering decisions should be interpreted as correlations: custody decisions are, for sure, correlated to unobservable characteristics of children (for instance, personality).

We consider three variables that capture with whom a child was living before the age of 7 , the age at which she should start attending school: living with the mother, living with the father, and being fostered. ${ }^{30}$ These variables allow us to compare correlations between custody and fostering decisions and primary school attendance. For custody and fostering decisions to mediate the positive link between being younger than 5 at survey date and increased school attendance, we would need to know with whom the child was living during the period between her parents' divorce and the age of 7 . However, reconstructing this variable from household information requires many assumptions to be build for the whole sample. ${ }^{31}$

\footnotetext{
${ }^{30}$ Recovering retrospective information on who had custody of a child during a specific period is a strenuous effort and there are a few additional missing values. Estimating the regressions from Table 2 on this sample does not change the results.

${ }^{31}$ The variable measure custody and fostering decisions between divorce date and the age of 7 can be defined for a subsample of children. When considering children who were 5 and younger when their mother divorced, the correlation
} 
Our analysis follow three successive steps. First, we check whether children whose parents divorce when they are 5 or younger had different caregivers than their older siblings. As expected, children who were younger than 5 years old are less likely to have lived full time with their mother (before 7) than their older siblings were. Conversely, children who were younger than 5 at the time of divorce are 9 percentage points more likely to have stay with their father, and 13.7 percentage points to have been fostered before the age of 7 (siblings fixed effects, Table A3 in Appendix).

Second, we check whether these variables are associated to a higher likelihood to attend primary school (columns (1) and (2), Table 3): they are not, apart for being fostered before the age of 7 (column (1)). This effect disappears when introducing the fixed effects: it seems that the effects of fostering are heterogeneous (a finding in line with Beck et al. (2015)). Third, we add these three variables to the regressions displayed in Table 2. When the interaction between age at divorce and these new variables is added to the model (columns (3) and (4), Table 3), the coefficient on the age at divorce remains significant, but the new variables are not significant, which is consistent with results from the second step. These findings suggest that custody and fostering decisions are not what drives our results.

\subsubsection{Financial and non-financial resources}

As custody and fostering decisions after a divorce do not seem likely to be what drives the results observed, we now discuss two potential changes. First, changes in the levels of resources women have access to after a divorce. Second, changes in the level of control over resources and in bargaining power.

As most children live with their mothers after the divorce we discuss mothers' situation. As men are to provide for their families, a divorce should not represent a positive income shock for a father, unless he stops contributing to his children's living expenses.

The first potential channel is that a divorce increases access to resources, either permanently or temporarily, for some women. A divorce could result in an improved economic situation for women in case it allows them to be more independent including financially (Dial, 2008) or if she divorces a man who did not contribute to household expenses. This improved financial situation does not seem consistent with the fact that results on primary school attendance are not replicated when we consider primary school completion. A more temporary shock would be more in line with the patterns observed. Women might benefit from additional transfers from their family network after their divorce. This support may allow recently divorced women to send their young children to school: even if public schools do not charge a fee, there are additional expenses related between the variable defined as custody/fostering before 7 and the one defined for the post divorce period is 0.8 . 
Table 3: Primary attendance: custody and fostering

\begin{tabular}{|c|c|c|c|c|}
\hline & $\begin{array}{c}\text { (1) } \\
\text { LPM }\end{array}$ & $\begin{array}{l}\text { (2) } \\
\text { SFE }\end{array}$ & $\begin{array}{c}\text { (3) } \\
\text { LPM }\end{array}$ & $\begin{array}{l}\text { (4) } \\
\text { SFE }\end{array}$ \\
\hline Dependent variable & \multicolumn{4}{|c|}{ Ever attended primary school } \\
\hline \multicolumn{5}{|c|}{ Panel A: Interaction with Living with father } \\
\hline \multicolumn{5}{|l|}{ Age at divorce } \\
\hline \multirow[t]{2}{*}{$0-5$ y.o. } & & & $0.182^{* * *}$ & $0.163 * *$ \\
\hline & & & $(0.0532)$ & $(0.0645)$ \\
\hline \multirow[t]{2}{*}{ With father } & 0.00394 & -0.0435 & -0.00360 & $-0.0508+$ \\
\hline & $(0.0339)$ & $(0.0343)$ & $(0.0348)$ & $(0.0340)$ \\
\hline \multirow{2}{*}{ With father $\times 0-5$} & & & 0.0213 & 0.0614 \\
\hline & & & $(0.120)$ & $(0.156)$ \\
\hline Controls & Yes & Yes & Yes & Yes \\
\hline $\mathrm{N}$ observations & $7,215.00$ & $7,215.00$ & $7,215.00$ & $7,215.00$ \\
\hline $\mathrm{N}$ families & & 2,151 & & 2,151 \\
\hline \multicolumn{5}{|c|}{ Dependent variable Ever attended primary school } \\
\hline \multicolumn{5}{|c|}{ Panel B: Interaction with Fostered } \\
\hline \multicolumn{5}{|l|}{ Age at divorce } \\
\hline \multirow[t]{2}{*}{ 0-5 у.о. } & & & $0.185 * * *$ & $0.156^{* *}$ \\
\hline & & & $(0.0511)$ & $(0.0731)$ \\
\hline \multirow[t]{2}{*}{ Fostered } & $-0.100 * * *$ & -0.0180 & $-0.107^{* * *}$ & -0.0232 \\
\hline & $(0.0292)$ & $(0.0267)$ & $(0.0299)$ & $(0.0269)$ \\
\hline \multirow[t]{2}{*}{ Fostered $\times 0-5$} & & & 0.0740 & 0.0931 \\
\hline & & & $(0.110)$ & $(0.159)$ \\
\hline Controls & Yes & Yes & Yes & Yes \\
\hline $\mathrm{N}$ observations & $7,250.00$ & $7,250.00$ & $7,250.00$ & $7,250.00$ \\
\hline $\mathrm{N}$ families & & 2,159 & & 2,159 \\
\hline \multicolumn{5}{|c|}{ 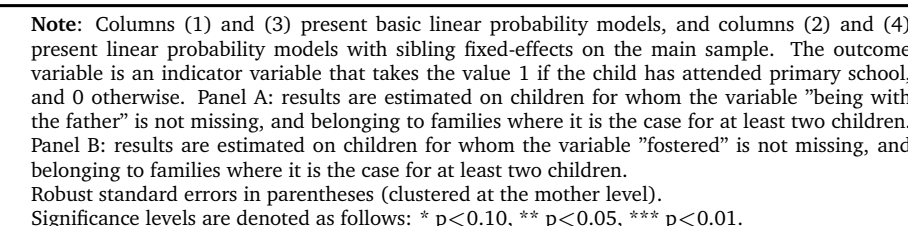 } \\
\hline
\end{tabular}

to education, such a transport fees and school supplies. After the divorce, women may also be able to foster more easily one of their children to a relative who can provide better educational opportunities. This support might fade away in the longer run, especially when women remarry.

We cannot test directly how income and resources vary following a divorce, as we do not have retrospective data on the economic condition at the time of divorce. However, the panel dimension of the PSF survey allows to describe how per capita household consumption evolved after a divorce. We use data on the 43 women who divorced the father of their children between the two survey waves. For these women, the annual per capita household consumption seems to be rather stable (397455 FCFA per year per capita in 2011 against 388034 in 2006). It seems that, on average, these women did not experience dramatic changes in their situation: this is still compatible with a short term positive economic shock after a divorce.

While a short-term increase in resources following the divorce could be what explains our 
results, a positive income shock that takes place before the divorce and allows women to divorce would be a confounding factor. The income shock could allow women to get divorced and increase as well the likelihood that younger children are sent to school. Yet it is unlikely that positive income shocks prior to divorce dates are what drive our results as positive income shocks are either very rare (as few women inherit from their parents, this type of windfall income is unlikely to occur often explain a large share of divorces) or likely to happen to women who would already having the means to divorce (it is likely that women who get a formal job are already well-off enough to divorce if they wish so).

The second potential channel is that some women see their bargaining power increases after a divorce. The link between women's bargaining power and the investment in the education of their children has been documented (Menon et al., 2014; Doss, 2013). A divorce may result in an increased decision-making power regarding decisions about the child for the mother, which may in turn increase the likelihood that her child attends school.

The fact that our results are likely to be driven by children of uneducated mothers is consistent with both the channel of an increased access to resources and with the channel of an increase in bargaining power. Indeed, uneducated women are more likely to have been in more precarious economic situation and in a situation where they lacked of bargaining power regarding a decision such as school attendance than more educated women. They may also be the ones who decide to invest more in the human capital of the child as an (future) insurance means in the absence of the economic support of a husband and potentially of their family. Uneducated women might not be able to sustain this investment in their children's education. Once they remarry, they may lose bargaining power and invest less in their children from their first union if their new husband does not value this kind of investment. Additionally, the opportunity cost of schooling for a young child is lower than for an older child, who can help the adults at home or outside (especially in a single-parent household). Last, uneducated women might not have the ability to support their children's learning, which might result in increased grade repetition rates.

\section{Robustness}

Until now, we have analyzed the correlation of having a primary schooling (defined for children older than 7) on being younger than 5 at time of divorce. We first conduct a sensitivity analysis and report the results for different definitions of the sample and of the variable of interest, then we check whether the identifying families are selected. Since being younger than 5 at divorce date is not correlated with a higher propensity to complete primary schooling, we do not perform robustness tests on this matter. 


\subsection{Sensitivity check}

Table 4 reports the results of regressions of the outcome variable (primary schooling, defined at different ages) on being younger than a certain threshold at time of divorce, with the usual set of controls (birth rank, birth year, gender).

\section{Sensitivity to sample definition}

Since some children tend to enter school late (section 3.2), attendance to primary school is not definitely defined for the whole sample at the age of 7 . We run therefore the same specification, but making the age at which our outcome is defined vary between 6 and 10. We notice that the coefficient (for a given threshold for the age at divorce variable) does not vary much. Moving from the first column to the fifth one implies reducing the sample size, as children are excluded from the sample each time the age threshold is set higher (as seen from the number of observations and of families, both identifying and not identifying). It is reassuring that the magnitude of coefficients does not vary too much across column. ${ }^{32}$ For threshold fixed at older ages, it seems that the main issue is that power is too low to detect effects when we increase the age threshold for inclusion into the sample, as noticeable in the number of identifying families.

\section{Sensitivity to "treatment" definition}

When comparing results across lines and within columns, we compare results of regression when we consider other age groups at divorce that the group of ages 0 to 5 . As expected, our results depend on how the age cutoff for this variable varies: varying the age cutoff is equivalent to changing who is considered as "treated" (younger than the cutoff at the time of divorce) and who is considered as "not treated" (older than the cutoff at the time of divorce). The higher the cut-off, the lower the coefficient of interest (except for the cut-off 4 years old). This is consistent with the Figure 4, which shows that there is no difference between children whose parents divorced when they were 6, 7, 8 or 9 and children who were 10 and older when their parents divorced. This results are consistent with the fact that children are supposed to start attending primary school at age 6 (and that most of them start school at age 6 or 7, as shown in Figure 3).

\section{Sensitivity to the definition of the controls: Sample made up only of children whose parents divorced}

\footnotetext{
${ }^{32}$ Moreover, the characteristics of mothers included in the sample do not vary significantly when the age threshold varies (Table A4).
} 
Table 4: Age thresholds on sample selection (criterion A) and on age at divorce

\begin{tabular}{|c|c|c|c|c|c|}
\hline \multicolumn{6}{|c|}{ Dependent variable: Ever enrolled in primary school } \\
\hline $\begin{array}{l}\text { Age- Sample } \\
\text { divorce }\end{array}$ & $\geq 6$ & $\geq 7$ & $\geq 8$ & $\geq 9$ & $\geq 10$ \\
\hline \multicolumn{6}{|l|}{ Age at divorce } \\
\hline \multirow[t]{2}{*}{$0-4$ y.o. } & 0.115 & 0.115 & 0.100 & 0.0941 & 0.112 \\
\hline & $(0.112)$ & $(0.120)$ & $(0.117)$ & $(0.121)$ & $(0.135)$ \\
\hline Identifying children & 139 & 127 & 88 & 75 & 62 \\
\hline Identifying families & 50 & 45 & 33 & 30 & 25 \\
\hline \multicolumn{6}{|l|}{ Age at divorce } \\
\hline \multirow[t]{2}{*}{ 0-5 y.o. } & $0.132 * *$ & $0.167 * * *$ & $0.198 * * *$ & $0.147^{* *}$ & $0.140+$ \\
\hline & $(0.0642)$ & $(0.0611)$ & $(0.0694)$ & $(0.0707)$ & $(0.0920)$ \\
\hline Identifying children & 157 & 134 & 108 & 94 & 63 \\
\hline Identifying families & 55 & 47 & 39 & 35 & 25 \\
\hline \multicolumn{6}{|l|}{ Age at divorce } \\
\hline \multirow[t]{2}{*}{ 0-6 у.о. } & & $0.0910 *$ & $0.122 *$ & 0.0892 & 0.0599 \\
\hline & & $(0.0546)$ & $(0.0628)$ & $(0.0635)$ & $(0.0742)$ \\
\hline Identifying children & & 141 & 119 & 108 & 81 \\
\hline Identifying families & & 49 & 42 & 39 & 31 \\
\hline \multicolumn{6}{|l|}{ Age at divorce } \\
\hline \multirow[t]{2}{*}{ 0-7 у.о. } & & & 0.0426 & 0.0519 & 0.0448 \\
\hline & & & $(0.0874)$ & $(0.0919)$ & $(0.0957)$ \\
\hline Identifying children & & & 110 & 96 & 79 \\
\hline Identifying families & & & 37 & 32 & 28 \\
\hline \multicolumn{6}{|l|}{ Age at divorce } \\
\hline \multirow[t]{2}{*}{$0-8$ y.o. } & & & & 0.0609 & 0.00980 \\
\hline & & & & $(0.0805)$ & $(0.0827)$ \\
\hline Identifying children & & & & 85 & 74 \\
\hline Identifying families & & & & 28 & 26 \\
\hline $\mathrm{N}$ children (d) & 284 & 263 & 225 & 209 & 190 \\
\hline $\mathrm{N}$ families (d) & 108 & 101 & 87 & 81 & 74 \\
\hline $\mathrm{N}$ children (all) & 7,836 & 7,268 & 6,688 & 6,140 & 5,650 \\
\hline $\mathrm{N}$ families (all) & 2,300 & 2,166 & 2,027 & 1,902 & 1,787 \\
\hline \multicolumn{6}{|c|}{$\begin{array}{l}\text { Note: Columns show results when varying the age cutoff for the sample (Criterion A: at what age do we } \\
\text { consider the outcome variable to be defined?). Lines show results when varying the age cutoff for the } \\
\text { AgeAtDivorceGroup variable (above which age is primary enrollment decision not affected by parental } \\
\text { divorce?). } \\
\text { Cells Each cell reports the coefficient on the variable AgeAtDivorceGroup of a regression using the SFE } \\
\text { model. The outcome variable is an indicator variable which takes the value } 1 \text { if the child has attended or } \\
\text { attends formal (primary or secondary) school. Control variables include: quadratic control for birth year, birth } \\
\text { order indicators (4 categories) and an indicator variable that takes the value } 1 \text { if the child is a girl. Robust } \\
\text { standard errors in parentheses (clustered at the mother level). } \\
\text { Significance levels are denoted as follows: * } \mathrm{p}<0.10 \text {, }{ }^{* *} \mathrm{p}<0.05, * * * \mathrm{p}<0.01 \text {. } \\
\text { Source: PSF2. }\end{array}$} \\
\hline
\end{tabular}

When we run the estimation on the sample made up of only children whose parents divorced, we find similar results (columns (5) and (6), Table A5): being younger than 5 at the time of divorce is still positively and significantly correlated with primary school attendance, in the basic LPM and in the SFE specifications. The order of magnitude of this coefficient is also similar.

\section{Alternative specification: sibling-difference model}


We report results using an alternative strategy: a sibling-difference model (columns (11) to (13) in the Table A5). For each family, we select the pair of siblings that is the closest to the age of 5 at the time of divorce ${ }^{33}$. The sample size is limited, but we find that within identifying pairs, younger siblings are more likely to have attended primary school then their older sibling compared to pairs of children who were older than the age of 5 at the time of divorce.

\subsection{Is there selection of identifying families on observable variables?}

While unobserved factors cannot, by definition, be observed, we show that mothers in identifying families (in the SFE specification) are similar to other divorced mothers. Table 5 displays the characteristics of mothers according to whether they are identifying mothers, mothers whose children were all younger than 5 at divorce date, or mothers whose children were all older than 6 at divorce date. Women who divorced when all their children (older than 7 at survey date) were older than 5 have been married for longer (as more time elapsed between the birth of last child and their divorce) and have less children younger than 25 (due to the censorship to the right of the data) than women who divorced when at least one of their children was younger than 5 and one older. Women who divorced when all their children (older than 7 at survey date) were younger than 5 have been married for a shorter period (on average, 5 years, which is consistent with having two children who were younger than 5) and less children were born to their last union (which is consistent with a shorter marriage) than women who divorced when at least one of their children was younger than 5 and one older.

The main significant differences are due to the fact that the age of women, their number of children, and the length of marriage are all correlated. These structural demographic differences do not appear to be what explains our results. Moreover, there are no significant differences in education levels of mothers. Younger mothers (divorced with children under 5) also seem to be more educated, which is consistent with the trends in education described in section 3 . The mothers of children on which our coefficient of interest is estimated hence do not appear to be different from other mothers who divorce with children, apart from the structural demographic factors.

\footnotetext{
${ }^{33}$ The selection process is as follows. If there is a pair of children with one older than 5 and one younger, we select this pair by selecting the child who is the closest to each side of the cutoff. If there is no such pair, we choose the two children who were the closest to age 5 at the time of divorce. We drop observations from two families for which children closest to the threshold include twins.
} 
Table 5: Characteristics of families according to the age distribution of children at divorce

\begin{tabular}{|c|c|c|c|c|c|}
\hline & $\begin{array}{c}\text { (1) } \\
\text { Identifying }\end{array}$ & $\begin{array}{c}\text { (2) } \\
\text { All children } \\
\text { older than } 5\end{array}$ & $\begin{array}{c}\text { (3) } \\
\text { all children } \\
\text { younger than } 5\end{array}$ & $\begin{array}{c}\text { (4) } \\
\text { Diff. identifying } \\
\text { all older }\end{array}$ & $\begin{array}{l}\text { (5) } \\
\text { Diff. identifying } \\
\text { all younger }\end{array}$ \\
\hline Age & 37.81 & 42.89 & 35.65 & $5.08 * * *$ & -2.16 \\
\hline \multicolumn{6}{|l|}{ Highest education level } \\
\hline No formal education & 0.64 & 0.67 & 0.47 & 0.02 & -0.17 \\
\hline Primary & 0.27 & 0.14 & 0.47 & -0.13 & 0.20 \\
\hline Secondary or higher & 0.09 & 0.19 & 0.06 & 0.11 & -0.03 \\
\hline \multicolumn{6}{|l|}{ Household Consumption } \\
\hline Food expenditures (hh) & 156730.92 & 196294.67 & 123768.48 & 39563.75 & -32962.44 \\
\hline Other expenditures (hh) & 143408.60 & 128730.60 & 151600.76 & -14678.00 & 8192.16 \\
\hline \multicolumn{6}{|l|}{ Family composition } \\
\hline Number of children alive & 5.00 & 4.00 & 4.92 & -1.00 & -0.08 \\
\hline Number of children ( $\leq 25$ y.o) & 4.02 & 3.11 & 4.18 & $-0.91 * * *$ & 0.16 \\
\hline Number of children - last union ${ }^{\mathrm{a}}$ & 2.96 & 2.78 & 2.18 & -0.17 & $-0.78 * *$ \\
\hline Last marriage duration & 9.94 & 16.14 & 4.70 & $6.20 * *$ & $-5.24 * *$ \\
\hline Number of mothers & 47 & 37 & 17 & 84 & 64 \\
\hline
\end{tabular}

Note: The table presents characteristics of women and their families according to the age distribution of children at the time of divorce. Column (4) presents the results of a difference in average test between identifying families and families where all the children were older than 5 at the time of the survey. Column (5) presents the results of a difference in average test between identifying families and families where all the children were younger than 5 at the time of the survey.

Sample: All mothers surveyed in 2011 with at least a child younger than 25 and two children older than 7 at the time of the survey. Significance of the $\mathrm{t}$-test of the difference is reported in column 3. P-values are denoted as follows: $+\mathrm{p}<0.15,{ }^{*} \mathrm{p}<0.10, * * \mathrm{p}<0.05, \cdots * *$ $\mathrm{p}<0.01$.

\subsection{Sample composition: Relaxing criteria on half-siblings (B) and on number of children (C)}

Relaxing criterion B: Including half-siblings in the sample We report regression results from both the LPM specification and the SFE specification in columns (7) and (8) of Table A5 in Appendix. The sample includes 473 additional observations (children belonging to 151 families instead of 101 in our main sample): 153 are half-siblings of children whose mothers divorced. The results are similar to what we find when removing the half-siblings from the sample.

\section{Relaxing criterion C: Including children who do not have a sibling older than 7 in the sample}

As we include children who do not have a full sibling that is older than 7 , we cannot estimate the SFE model. Results from our LPM without SFE are reported in columns (9) and (10) of Table A5. The sample includes 1201 additional observations, and among them, 122 are children of divorced parents. Being younger than 5 remains significantly and positively correlated with primary school attendance, but has a slightly lower magnitude (0.142) than the coefficient estimated on the main sample (0.168).

Figure A2 shows the results of the linear probability model when binary variables for each age 
at divorce are introduced (ages 0 to 6). Model 1 is reported for comparison purposes (sample of 2 children of a divorced mother). The sample used to estimate the model 2 includes all children older than 7 who parents divorced (even the ones who do not have a sibling over 7 to be compared to). The sample used to estimate the models 3 and 4 (controls included) include all children older than 7, whether or not their parents are divorced. The coefficients from these 3 models seem to be similar to the coefficients from model 1, except for age 4 and 5 at divorce, where they seems to be lower: this pattern is consistent with the lower coefficient on being younger than 5 when estimated on the larger sample. The coefficient associated to being 6 at divorce date is almost exactly at 0 whichever the sample and model considered. These findings suggest that the results estimated on the main sample are not overly sensitive to the inclusion of children who do not have a sibling older than 7 .

\subsection{Extending the definition of formal schooling to Qur'anic Education}

We have investigated the links between divorce primary schooling attendance, looking for now only at formal schooling. But as explained earlier, Qur'anic education is also widespread is Senegal. We use the same specification than before, pooling formal and Qur'anic education. Results are shown in Table 6. Age at divorce does not seem to have an impact on school attendance. When adding controls, the coefficient associated to being younger than 5 at time of divorce is even negative (but not significant). It means that younger children do not have a higher probability to enter school, once both types of schools are pooled. It suggests that younger children at time of divorce tend to enter more formal schools rather than Qur'anic schools, with potentially a substitution effect. 
Table 6: Effect of parental separation, including Qur'anic school schools

\begin{tabular}{|c|c|c|}
\hline & (1) & $(2)$ \\
\hline Specification & SFE & SFE \\
\hline Sample & \multicolumn{2}{|c|}{ Main sample ${ }^{a}$} \\
\hline Dependent variable & \multicolumn{2}{|c|}{ Ever attended primary school or Qur'anic school } \\
\hline \multicolumn{3}{|l|}{ Age at divorce } \\
\hline \multirow[t]{2}{*}{$0-5$ y.o. } & 0.00612 & -0.0278 \\
\hline & $(0.0454)$ & $(0.0473)$ \\
\hline Controls & No & Yes \\
\hline Share primary & 0.87 & 0.87 \\
\hline $\mathrm{R}^{2}$ & 0.00 & 0.04 \\
\hline $\mathrm{N}$ observations & 6,722 & 6,722 \\
\hline $\mathrm{N}$ families & 2,049 & 2,049 \\
\hline $\mathrm{N}$ identifying obs. (0-5) & 124 & 124 \\
\hline $\mathrm{N}$ identifying families $(0-5)$ & 45 & 45 \\
\hline \multicolumn{3}{|c|}{$\begin{array}{l}\text { Note: Linear probability model with sibling fixed-effects. The outcome variable is an indicator variable } \\
\text { that takes the value } 1 \text { if the child has attended or attends either formal primary school or Qur'anic school. } \\
\text { Control variables include: quadratic control for birth year, birth order indicators ( } 4 \text { categories) and an } \\
\text { indicator variable that takes the value } 1 \text { if the child is a girl. } \\
\text { a Main sample: Children who are older than } 7 \text { at survey date, only when they belong to a family in } \\
\text { which two children are } 7 \text { or older at survey date. The number of observations is lower than in the main } \\
\text { estimation because the variable coranic is missing for some observations. } \\
\text { Robust standard errors in parentheses (clustered at the mother level). } \\
\text { Significance levels are denoted as follows: }{ }^{*} \mathrm{p}<0.10,{ }^{* *} \mathrm{p}<0.05 \text {, }{ }^{* * *} \mathrm{p}<0.01 \text {. }\end{array}$} \\
\hline \multicolumn{3}{|l|}{ Source: PSF2. } \\
\hline
\end{tabular}

\section{Conclusion}

Using a dataset that records detailed life histories, we find that children's educational outcomes do not seem to be negatively affected by their parents' divorce. This finding holds when controlling for unobservable characteristics common to the siblings. Not all the endogeneity is removed: there could still remain differences in unobservable characteristics between siblings as well as selection into the timing of divorce with respect to family composition. The results on primary school attendance suggest that parents are able to invest more in the education of their younger children. However, the results on primary school completion suggest that, if any, the increased investment in education after a divorce does not persist in the longer run.

As the impact of divorce does not seem to be negative for children, at least when considering basic primary education, it alleviates the concerns some people raise over increasing divorce rates. Further research is needed to understand what might drive the effects we observe as well as potential heterogeneity between families. 


\section{References}

Amato, P. R. (2000). The Consequences of Divorce for Adults and Children. Journal of Marriage and Family, 62(4):1269-1287.

Andre, P. and Demonsant, J.-L. (2014). Substitution between Formal and Qur'Anic Schools in Senegal. The Review of Faith and International Affairs, 12(2):61-65.

Beck, S., Vreyer, P. D., Lambert, S., Marazyan, K., and Safir, A. (2015). Child fostering in Senegal. Journal of Comparative Family Studies, 46(1):57-73.

Beegle, K., De Weerdt, J., and Dercon, S. (2006). Orphanhood and the Long-Run Impact on Children. American Journal of Agricultural Economics, 88(5):1266-1272.

Beegle, K., De Weerdt, J., and Dercon, S. (2010). Orphanhood and human capital destruction: Is there persistence into adulthood? Demography, 47(1):163-180.

Björklund, A. and Sundström, M. (2006). Parental separation and children's educational attainment: A siblings analysis on Swedish register data. Economica, 73(292):605-624.

Bratberg, E., Rieck, K. M. E., and Vaage, K. (2014). Intergenerational earnings mobility and divorce. Journal of Population Economics, 27(4):1107-1126.

Case, A. and Ardington, C. (2006). The impact of parental death on school outcomes: Longitudinal evidence from south africa. Demography, 43(3):401-420.

Chae, S. (2016). Parental divorce and children's schooling in rural Malawi. Demography, 53(6):1743-1770.

Chehami, J. (2016). Les familles et le daara au sénégal. Afrique contemporaine, (1):77-89.

Cissé, F., Daffé, G., and Diagne, A. (2004). Les inégalités dans l'accès à l'éducation au sénégal. Revue d'économie du développement, 12(2):107-122.

Clark, S. and Brauner-Otto, S. (2015). Divorce in sub-Saharan Africa: Are Unions Becoming Less Stable? Population and Development Review, 41(4):583-605.

Clark, S. and Hamplová, D. (2013). Single motherhood and child mortality in sub-saharan africa: A life course perspective. Demography, 50(5):1521-1549.

De Vreyer, P., Lambert, S., Safir, A., and Sylla, M. (2008). Pauvreté et structure familiale, pourquoi une nouvelle enquête. Stateco, (102):261-275. 
Dial, F. B. (2008). Mariage et divorce à Dakar: itinéraires féminins. KARTHALA Editions.

Doss, C. (2013). Intrahousehold bargaining and resource allocation in developing countries. The World Bank Research Observer, 28(1):52-78.

Dumas, C. and Lambert, S. (2011). Educational Achievement and Socio-economic Background: Causality and Mechanisms in Senegal. Journal of African Economies, 20(1):1-26.

Ermisch, J. F. and Francesconi, M. (2001). Family structure and children's achievements. Journal of population economics, 14(2):249-270.

Francesconi, M., Jenkins, S. P., and Siedler, T. (2010). Childhood family structure and schooling outcomes: evidence for Germany. Journal of Population Economics, 23(3):1073-1103.

Gnoumou Thiombiano, B., LeGrand, T. K., and Kobiané, J.-F. (2013). Effects of Parental Union Dissolution on Child Mortality and Child Schooling in Burkina Faso. Demographic Research, 29:797-816.

Ito, S., Lepine, A., and Treibich, C. (2018). The effect of becoming a registered sex worker in Senegal on health and wellbeing. Health economics, 27(11):1627.

Lagoutte, S., Bengaly, A., Youra, B., Fall, P. T., and Danish Institute for Human Rights (2014). Rupture du lien matrimonial, pluralisme juridique et droits des femmes en Afrique de l'Ouest francophone. Danish Institute for Human Rights, Copenhagen. OCLC: 900293711.

Lambert, S., van de Walle, D., and Villar, P. (2019). Towards Gender Equity in Development, chapter Marital trajectories, women's autonomy and women's wellbeing in Senegal. Oxford University Press, Oxford.

Le Forner, H. (2020). Age At Parents' Separation and Children Achievement: Evidence From France Using a Sibling Approach. Annals of Economics and Statistics, (forthcoming).

Marazyan, K. (2015). Resource Allocation in Extended Sibships: An Empirical Investigation for Senegal. Journal of African Economies, 24(3):416-452.

Menon, N., Van Der Meulen Rodgers, Y., and Nguyen, H. (2014). Women's land rights and children's human capital in vietnam. World Development, 54:18-31.

Ndaruhutse, S. (2008). Grade repetition in primary schools in Sub-Saharan Africa: an evidence base for change.

Niang, F. (2014). L'école primaire au sénégal: éducation pour tous, qualité pour certains. Cahiers de la recherche sur l'éducation et les savoirs, (13):239-261. 
Smith-Greenaway, E. (2020). Does parents' union instability disrupt intergenerational advantage? an analysis of Sub-Saharan Africa. Demography, pages 1-29.

van de Walle, D. (2013). Lasting Welfare Effects of Widowhood in Mali. World Development, 51:1-19. 


\section{Appendix A Figures}

Figure A1: With whom do children of divorced parents live?
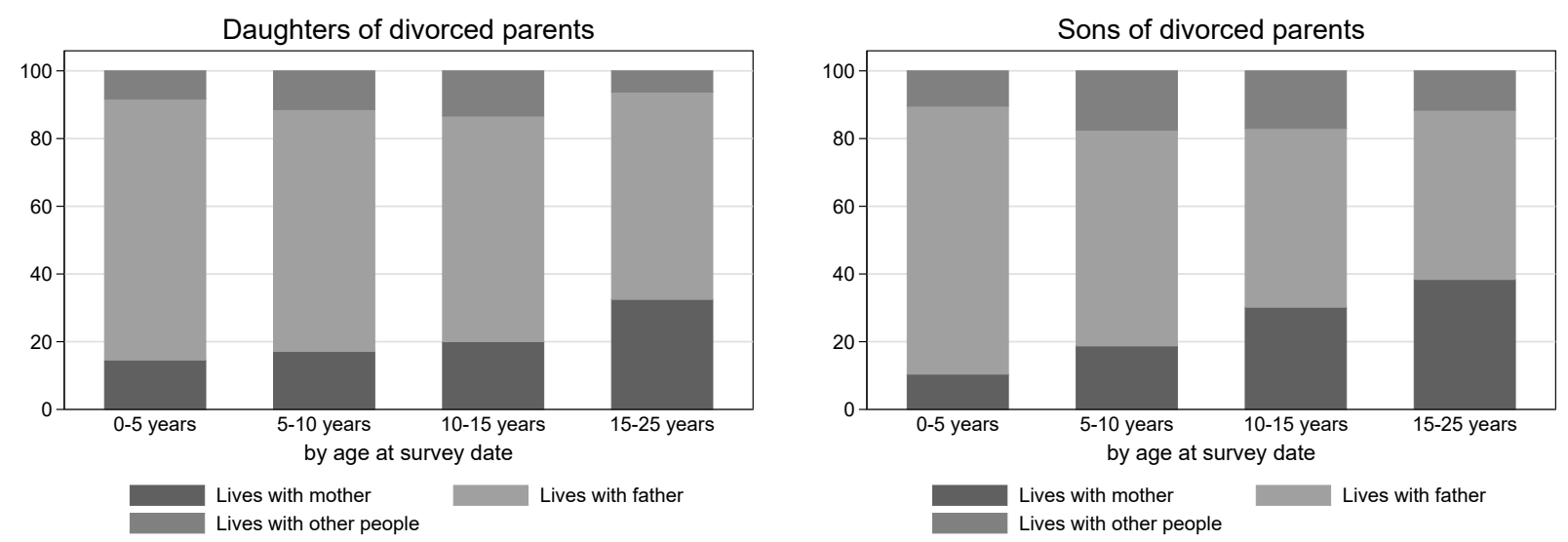

Note:Left panel: Sample: girls younger than 25 whose parents divorced. Right panel: Sample: boys younger than 25 whose parents divorced. 
Figure A2: Coefficients on age at divorce - Relaxing criterion A

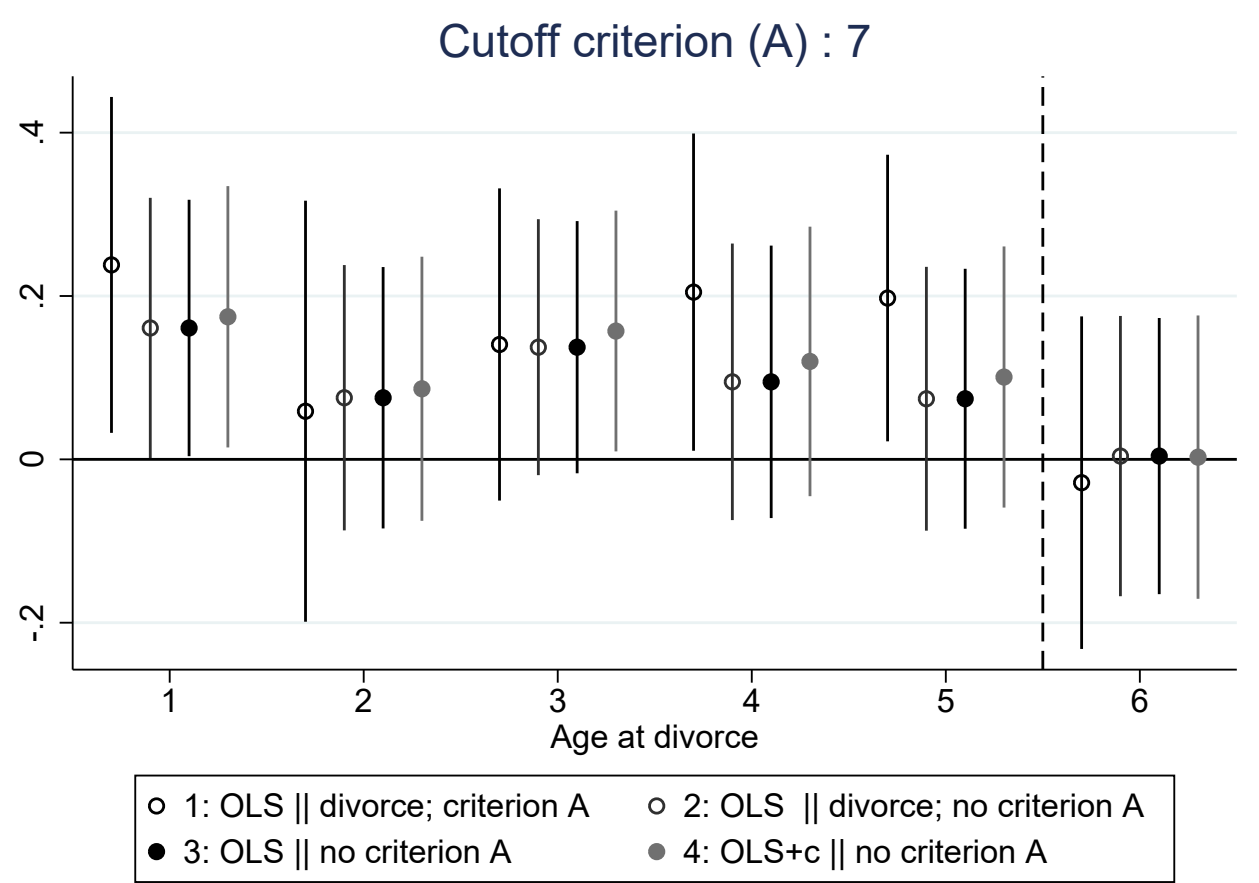

Note: Specifications: (1) LPM only on children of divorced parents with criterion A; (2) LPM only on children of divorced parents without criterion A; (3) LPM (with additional variable Divorce) without criterion A; (4) LPM with controls and additional variable Divorce without criterion A. Criterion A: at least two observations (children) by group (family).

\section{Appendix B Additional tables}


Table A1: Determinants of school attendance

(1) (2)

\begin{tabular}{lccc}
\hline Dependent variable & Ever attended primary school & Primary or Qur'anic & Completed Primary School \\
Sample: children older than & 7 & 10 & 10 \\
Child is a girl & $0.0329^{* * * *}$ & $-0.0618^{* * *}$ & 0.00671 \\
& $(0.0110)$ & $(0.00841)$ & $(0.0123)$ \\
Birth rank & & & \\
Second child & $-0.0219^{* *}$ & -0.00143 & -0.0162 \\
& $(0.0125)$ & $(0.00908)$ & $(0.0155)$ \\
Third child & $-0.0390^{* * *}$ & -0.00467 & -0.00139 \\
& $(0.0148)$ & $(0.0108)$ & $(0.0178)$ \\
Fourth and more & $-0.0335^{* * *}$ & -0.00639 & -0.0251 \\
& $(0.0148)$ & $(0.0105)$ & $(0.0168)$ \\
Birth year & & & \\
Birth year & $7.247^{* * * *}$ & -0.487 & $20.79 * * *$ \\
& $(0.801)$ & $(0.585)$ & $(1.256)$ \\
Birth year squared & $-0.00182^{* * * *}$ & 0.000124 & $-0.00522^{* * *}$ \\
& $(0.000201)$ & $(0.000147)$ & $(0.000315)$ \\
Constant & $-7228.9^{* * *}$ & 478.4 & $-20712.8^{* * *}$ \\
& $(799.3)$ & $(584.2)$ & $(1252.1)$ \\
\hline Share schooling & 0.65 & 0.87 & 0.47 \\
Number of children & 8,382 & 7,825 & 6,582 \\
\hline Note & & & \\
\hline
\end{tabular}

Note: Linear probability models. In column (1), the outcome variable is an indicator variable that takes the value 1 if the child has attended or attends formal primary school. In column (2), the outcome variable is an indicator variable that takes the value 1 if the child has attended or attends either formal primary school or Qur'anic school. In column (3), the outcome variable is an indicator variable that takes the value 1 if the child has attended the 5th grade of primary school or higher level. Sample: Children older than 7 at the time of survey for column (1). Children older than 10 for columns (2) and (3). Robust standard errors in parentheses (clustered at the mother level).

Significance levels are denoted as follows: ${ }^{*} \mathrm{p}<0.10$, ${ }^{* *} \mathrm{p}<0.05,{ }^{* * *} \mathrm{p}<0.01$.

Source: PSF2.

Table A2: Schooling of children according to mother's characteristics

\begin{tabular}{|c|c|c|c|c|c|c|}
\hline Dependent variable & $\begin{array}{c}\text { (1) } \\
\text { Ever attended } \\
\text { primary school }\end{array}$ & $\begin{array}{c}\text { (2) } \\
\text { Ever attended } \\
\text { primary school }\end{array}$ & $\begin{array}{c}\text { (3) } \\
\text { Ever attended } \\
\text { primary school }\end{array}$ & $\begin{array}{c}\text { (4) } \\
\text { Completed } \\
\text { primary }\end{array}$ & $\begin{array}{c}\text { (5) } \\
\text { Completed } \\
\text { primary }\end{array}$ & $\begin{array}{c}\text { (6) } \\
\text { Completed } \\
\text { primary }\end{array}$ \\
\hline Mother has divorced & & $\begin{array}{l}0.0679 * * \\
(0.0315)\end{array}$ & $\begin{array}{c}0.0197 \\
(0.0292)\end{array}$ & & $\begin{array}{c}0.0355 \\
(0.0362)\end{array}$ & $\begin{array}{l}-0.00589 \\
(0.0338)\end{array}$ \\
\hline Primary (any) & $\begin{array}{l}0.319^{* * * *} \\
(0.0150)\end{array}$ & & $\begin{array}{l}0.327^{* * * *} \\
(0.0150)\end{array}$ & $\begin{array}{l}0.337 * * * * \\
(0.0157)\end{array}$ & & $\begin{array}{l}0.337^{\text {**** }} \\
(0.0157)\end{array}$ \\
\hline Secondary (any) & $\begin{array}{l}0.394^{* * * *} \\
(0.0157)\end{array}$ & & $\begin{array}{l}0.401^{* * * *} \\
(0.0158)\end{array}$ & $\begin{array}{l}0.393^{* * * * *} \\
(0.0156)\end{array}$ & & $\begin{array}{l}0.394^{* * * *} \\
(0.0156)\end{array}$ \\
\hline Unknown & $\begin{array}{l}0.106^{* * * *} \\
(0.0303)\end{array}$ & & $\begin{array}{l}0.112^{* * * *} \\
(0.0306)\end{array}$ & $\begin{array}{l}0.121^{* * * *} \\
(0.0334)\end{array}$ & & $\begin{array}{l}0.121^{\text {**** }} \\
(0.0335)\end{array}$ \\
\hline Controls & No & Yes & Yes & Yes & Yes & Yes \\
\hline Share schooling & 0.65 & 0.65 & 0.65 & 0.67 & 0.67 & 0.67 \\
\hline Number of children & 8,382 & 8,382 & 8,382 & 6,657 & 6,657 & 6,657 \\
\hline Dependent variable & Ever attended primary school & Ever attended primary school & Ever attended primary school & Completed primary & Completed primary & Completed primary \\
\hline
\end{tabular}


Table A3: Custody and fostering decisions after a divorce

\begin{tabular}{|c|c|c|c|c|c|c|}
\hline $\begin{array}{l}\text { Dependent variable } \\
\text { Specification }\end{array}$ & $\begin{array}{c}\text { (1) } \\
\text { With Mother } \\
\text { LPM }\end{array}$ & $\begin{array}{c}\text { (2) } \\
\text { With Mother } \\
\text { SFE }\end{array}$ & $\begin{array}{c}\text { (3) } \\
\text { With father } \\
\text { LPM }\end{array}$ & $\begin{array}{c}\text { (4) } \\
\text { With Father } \\
\text { SFE }\end{array}$ & $\begin{array}{c}\text { (5) } \\
\text { Fostered } \\
\text { LPM }\end{array}$ & $\begin{array}{c}(6) \\
\text { Fostered } \\
\text { SFE }\end{array}$ \\
\hline Sample & \multicolumn{6}{|l|}{ Main sample ${ }^{a}$} \\
\hline \multicolumn{7}{|l|}{ Age at divorce } \\
\hline 0-5 у.о. & $\begin{array}{l}-0.227 * * * \\
(0.0568)\end{array}$ & $\begin{array}{l}-0.216 * * * \\
(0.0793)\end{array}$ & $\begin{array}{l}0.128 * * * \\
(0.0433)\end{array}$ & $\begin{array}{l}0.0972 \% \\
(0.0551)\end{array}$ & $\begin{array}{l}0.0904 * \\
(0.0463)\end{array}$ & $\begin{array}{l}0.137 * * \\
(0.0652)\end{array}$ \\
\hline Controls & Yes & Yes & Yes & Yes & Yes & Yes \\
\hline Mean dep. var. & 0.90 & 0.90 & 0.05 & 0.05 & 0.06 & 0.06 \\
\hline $\mathrm{R}^{2}$ & 0.0100 & 0.0048 & 0.0074 & 0.0051 & 0.0067 & 0.0035 \\
\hline $\mathrm{N}$ observations ${ }^{\mathrm{b}}$ & 7,231 & 7,231 & 7,215 & 7,215 & 7,250 & 7,250 \\
\hline \multicolumn{7}{|c|}{$\begin{array}{l}\text { Note: Columns (1), (3) and (5): Linear probability model. Columns (2), (4) and (6): Linear probability model with sibling fixed effect. Columns } \\
\text { (1) and (2): The outcome variable is an indicator variable that takes the value } 1 \text { if the child has been full time with her mother until the age of } \\
7 \text { years old. Columns ( } 3 \text { ) and (4): The outcome variable is an indicator variable that takes the value } 1 \text { if the child has been coresiding with her } \\
\text { father (but not with her mother) before the age of } 7 \text { years old. Columns }(5) \text { and }(6): \text { The outcome variable is an indicator variable that takes } \\
\text { the value } 1 \text { if the child has been fostered before the age of } 7 \text { years old. } \\
\text { Control variables include: quadratic control for birth year, birth order indicators ( } 4 \text { categories) and an indicator variable that takes the value } 1 \text { if } \\
\text { the child is a girl. } \\
\text { a Main sample: Children who are older than } 7 \text { at survey date, only when they belong to a family in which two children are } 7 \text { or older at survey } \\
\text { date. } \\
\text { b The sample size varies because the outcome variable is missing for some observations. } \\
\text { Robust standard errors in parentheses (clustered at the mother level). } \\
\text { Significance levels are denoted as follows: }{ }^{*} \mathrm{p}<0.10,{ }^{* *} \mathrm{p}<0.05,{ }^{* * *} \mathrm{p}<0.01 \text {. }\end{array}$} \\
\hline
\end{tabular}

Table A4: Characteristics of families of divorced women according to the age composition of children at the time of the survey

2 children over $7 \quad 2$ children over $8 \quad 2$ children over $9 \quad 2$ children over 10

(1)

(2)

(3)

\section{Highest education level}

No formal education

0.62

Primary

0.26

0.12

0.61

0.62

0.64

Secondary or higher

Family structure

Age

Household Consumption

Food expenditures (hh)

Other expenditures (hh)

Number of children alive

Father's occupation

Farmer

State-employed or employer

Occupation unknown

Mother is remarried

0.27

0.27

0.23

0.12

0.11

0.12

Number of mothers
39.31

165676.44

139790.27

4.77

0.30

0.26

0.21

0.08

0.57

101

174286.81
137739.03

5.16

0.30

0.24

0.22

0.06

0.56

87
40.57

41.39

Note: The table presents characteristics of mothers and families according to the composition of the family at the time of the survey. Sample: All mothers surveyed in 2011 who have divorced, with at least a child younger than 25 and two children over 7 (over 8, over 9 and over 10) at the time of the survey for the column 1 (respectively column 2, 3 and 4). 
Table A5: Robustness checks: Primary school attendance

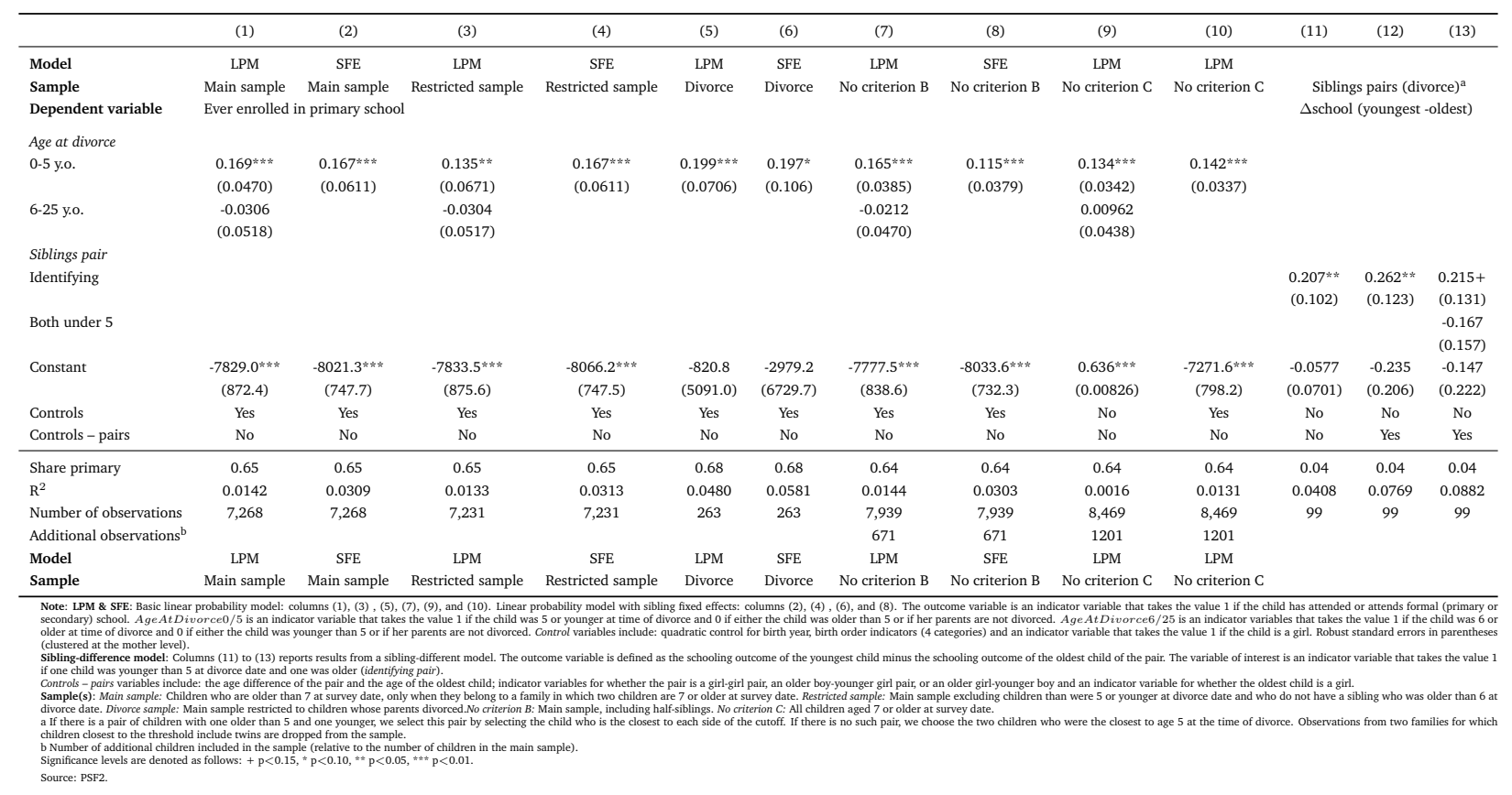

